Portland State University

PDXScholar

\title{
Oregon Survey of Initial Nursing Care for Infants with Cleft Lip \pm Palate
}

Kirsten Joy Lindaas

Portland State University

Follow this and additional works at: https://pdxscholar.library.pdx.edu/open_access_etds

Part of the Speech and Rhetorical Studies Commons

Let us know how access to this document benefits you.

\section{Recommended Citation}

Lindaas, Kirsten Joy, "Oregon Survey of Initial Nursing Care for Infants with Cleft Lip \pm Palate" (1997). Dissertations and Theses. Paper 5314.

https://doi.org/10.15760/etd.7187

This Thesis is brought to you for free and open access. It has been accepted for inclusion in Dissertations and Theses by an authorized administrator of PDXScholar. Please contact us if we can make this document more accessible: pdxscholar@pdx.edu. 


\section{THESIS APPROVAL}

The abstract and thesis of Kirsten Joy Lindaas for the Master of Science in Speech

Communication: Speech and Hearing Sciences were presented August 4, 1997, and accepted by the thesis committee and the department.

COMMITTEE APPROVALS:
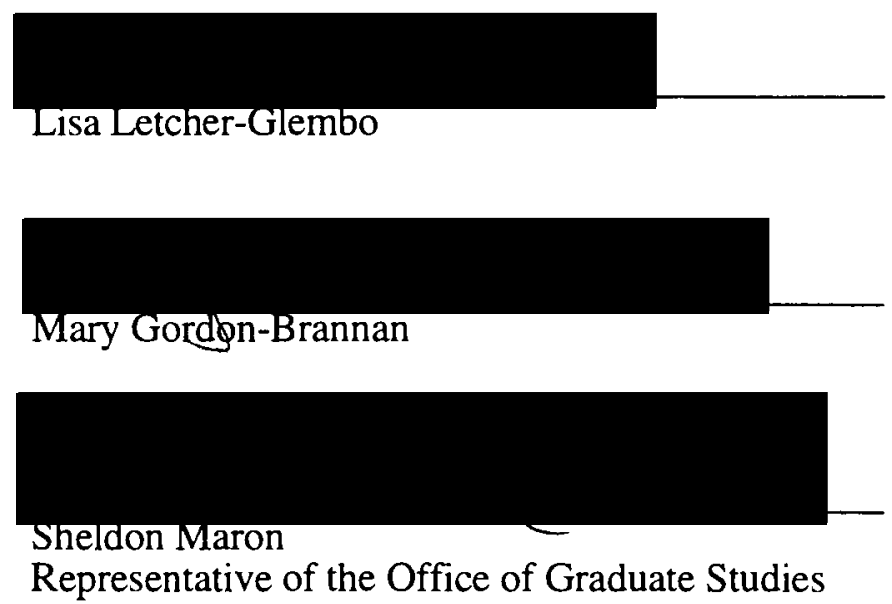

DEPARTMENT APPROVAL:

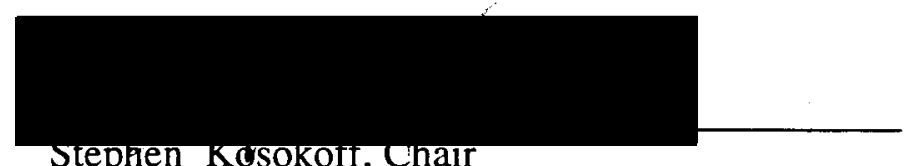

Stephen Kosokoft, Chair

Department of Speech Communication

$* * * * * * * * * * * * * * * * * * * * * * * * * * * * * * * * * * * * * * * * * * * * * * * * * * * * * * * * * * * * * * * * * * * * *$

ACCEPTED FOR PORTLAND STATE UNIVERSITY BY THE LIBRARY

by

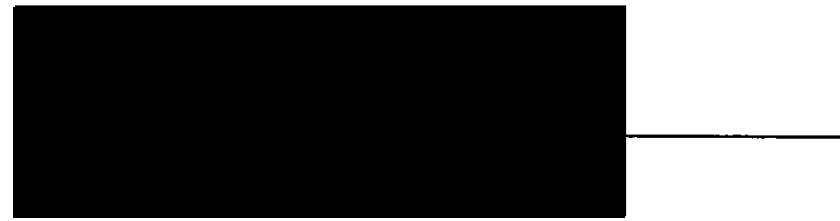

on

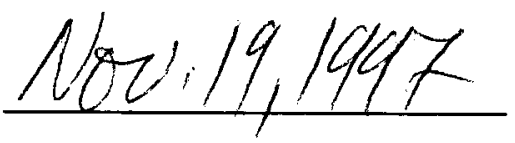




\begin{abstract}
An abstract of the thesis of Kirsten Joy Lindaas for the Master of Science in Speech Communication: Speech and Hearing Sciences presented August 4, 1997.
\end{abstract}

Title: Oregon Survey of Initial Nursing Care for Infants with Cleft Lip \pm Palate.

This study investigated the current status of initial nursing services provided by Oregon hospitals to families of newborns with cleft lip \pm palate. The research questions asked were: (a) Do hospitals provide assistance to parents of newborns with cleft lip \pm palate? (b) Do hospitals identify and refer to craniofacial specialists? (c) Is level of associated services provided to families of newborns with cleft lip \pm palate correlated to the number of births that occur at the hospital in which the infant was delivered? (d) Do hospitals provide inservice education programs in cleft lip and palate? (e) Do hospital staff perceive a need for inservice education programs? (f) Is the perceived need for inservices related to the number of births that occur at the subject's hospital?

Self-report surveys were mailed to the directors of nursing and directors of inservice education at 50 American Hospital Association registered Oregon hospitals. Twenty-six hospitals responded. 
Findings indicate that almost $70 \%$ of Oregon hospitals fail to provide trained professionals to counsel parents of newborns with clefts, $50 \%$ of the hospitals fail to provide pertinent reading materials, nearly $60 \%$ of the hospitals fail to offer training programs for new parents, $19 \%$ of the hospitals fail to provide adaptive feeding equipment, and $50 \%$ fail to refer to craniofacial specialists. Less than $27 \%$ of hospitals train their postnatal staff in management of cleft lip \pm palate; only $15 \%$ offer inservice education programs about cleft management. Spearman Rho and Chi Square analyses indicate the level of associated services provided to families of infants with cleft lip \pm palate is related to delivery rate at the hospital. A lower level of associated services are provided at hospitals in which fewer infants are delivered. Eighty-four percent of the respondents indicated inservice education programs regarding cleft lip \pm palate would be beneficial for nursing staff and other professionals. This perceived need for inservice education is found to be related to the delivery rate at the hospital, that is, the fewer the deliveries, the lower the perceived need is for inservice education. 
OREGON SURVEY OF INITIAL NURSING CARE FOR

INFANTS WITH CLEFT LIP \pm PALATE

by

KIRSTEN JOY LINDAAS

A thesis submitted in partial fulfillment of the

requirements for the degree of

MASTER OF SCIENCE

in

SPEECH COMMUNICATION:

SPEECH AND HEARING SCIENCES

Portland State University

1997 


\section{DEDICATION}

This thesis is dedicated to Craig Hamilton, my number one fan. 


\section{ACKNOWLEDGMENTS}

I must express my gratitude to my thesis advisor, Lisa Letcher-Glembo, for giving me direction, keeping me on task and spending countless hours editing my thesis. Sincere appreciation to my advisor, Mary Gordon-Brannan, and Sheldon Maron for providing insight and feedback about my thesis.

Special thanks go to many members of my family. I wish to express my appreciation to my parents, Keith and Sharon, for their love and support. Thank you to Erik and Andrew, my nephews, who helped me with the licking and sticking involved in sending out many survey packets. I could not have finished my survey without my computer. For that I have to acknowledge the aid given to me by Steve and Alison. Thanks go to Nancy and Michael for the encouragement they gave me from the beginning of this process.

Much love and gratitude to Craig. I thank you for cheering me along the way and assuring me that the finish line was within my reach. 
TABLE OF CONTENTS

PAGE

DEDICATION $\ldots \ldots \ldots \ldots \ldots \ldots \ldots \ldots \ldots \ldots \ldots \ldots \ldots \ldots \ldots$

ACKNOWLEDGMENTS $\ldots \ldots \ldots \ldots \ldots \ldots \ldots \ldots$ iii

LIST OF TABLES $\ldots \ldots \ldots \ldots \ldots \ldots \ldots \ldots \ldots$ vi

CHAPTER

I INTRODUCTION AND STATEMENT OF PURPOSE $\ldots \ldots \ldots \ldots$

Introduction $\ldots \ldots \ldots \ldots \ldots \ldots \ldots \ldots$

Statement of Purpose $\ldots \ldots \ldots \ldots \ldots \ldots \ldots \ldots$

Definition of Terms $\ldots \ldots \ldots \ldots \ldots \ldots \ldots \ldots$

II REVIEW OF THE LITERATURE $\ldots \ldots \ldots \ldots \ldots \ldots$

Nature of Clefting $\ldots \ldots \ldots \ldots \ldots \ldots \ldots \ldots$

Isolated Clefting Versus Clefting as a Component of a

Craniofacial Disorder Syndrome . . . . . . . . . . 11

Identification/Diagnosis of Clefting $\ldots \ldots \ldots \ldots \ldots \ldots 12$

Parental Reaction to Clefting $\ldots \ldots \ldots \ldots \ldots \ldots \ldots$

Overview of Early Issues: Increased Risk of Weight Loss,

Associated Anomalies, and Need for Surgery . . . . . . . 17

Intervention and Cleft Palate/Craniofacial Team Management $\ldots .18$ 
Parental Involvement with the Cleft Palate Team . . . . . . . . 20

Early Care of Individuals with Clefts . . . . . . . . . . 23

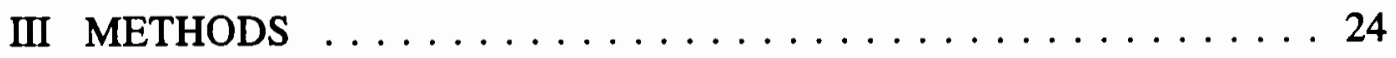

Subjects ....................... 25

Subject Selection ..................... 25

Subject Identification and Recruitment . . . . . . . . . 25

Subject Consent . . . . . . . . . . . . . . . . . 27

Response Rate . . . . . . . . . . . . . . . . . . 27

Subject Distribution . . . . . . . . . . . . . . 27

Demographics of Responding Subjects' Hospitals . . . . . . . . 28

Measures and Procedures . . . . . . . . . . . . . . . . . . 29

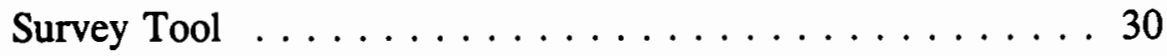

Use of Survey Tool to Respond to Research Questions . . . . . 33

Survey Response Reliability . . . . . . . . . . . . . . . . . 34

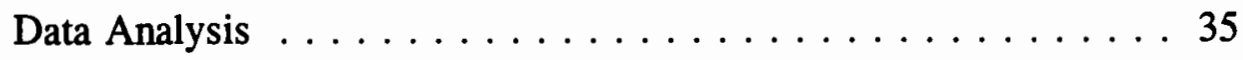

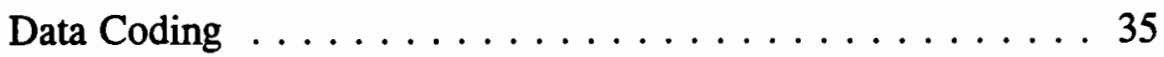

Descriptive and Quantitative Analysis ............ 35

IV RESULTS AND DISCUSSION $\ldots \ldots \ldots \ldots \ldots \ldots$

Results .................... 38

Study Limitations . . . . . . . . . . . . . . . . . . . . 38

Nursing Assistance to Parents of Newborns with Clefts . . . . 39

Nursing's Referral of Newborns with Clefts . . . . . . . . . . 41

Availability of Inservice Education Programs in CLP . . . . . 44

Perceived Need for Inservice Education Programs in CLP . . . 45

Descriptive Analysis of Subjects' Responses to Open-Ended

Survey Items . . . . . . . . . . . . . . 46

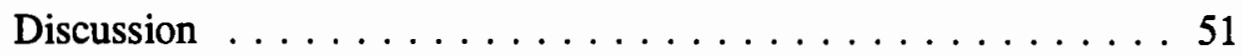


V SUMMARY AND IMPLICATIONS . . . . . . . . . . . . 58

Summary $\ldots \ldots \ldots \ldots \ldots \ldots \ldots \ldots \ldots$

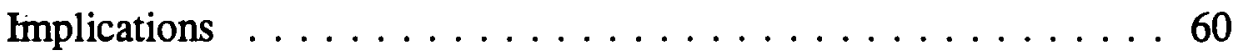

Clinical Implications $\ldots \ldots \ldots \ldots \ldots \ldots \ldots \ldots$

Future Research Implications $\ldots \ldots \ldots \ldots . \ldots 63$

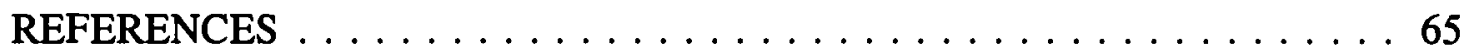

APPENDIXES

A List of Accredited Oregon Hospitals $\ldots \ldots \ldots \ldots \ldots \ldots$

B Cover Letter for Subjects $\ldots \ldots \ldots \ldots \ldots \ldots \ldots \ldots$

C Consent Form for Subjects $\ldots \ldots \ldots \ldots \ldots \ldots \ldots \ldots$

D Study Survey Questionnaire $\ldots \ldots \ldots \ldots \ldots \ldots \ldots \ldots$

E Subject Recruitment Follow-up Postcard . . . . . . . . . . 79

F Data Coding $\ldots \ldots \ldots \ldots \ldots \ldots \ldots \ldots \ldots \ldots$ 


\section{LIST OF TABLES}

TABLE

PAGE

1 Distribution of Subjects According to Job Title $\ldots \ldots \ldots \ldots 28$

2 List of Questionnaire Survey Items $\ldots \ldots \ldots \ldots \ldots \ldots \ldots$

3 Percentages of Subjects' Responses to Survey Items Related to Nursing Assistance to Newborns with Clefts . . . . . . . . 40

4 Percentages of Subjects' Responses to Survey Items Related to Nursing's Referral of Newborns with Clefts . . . . . . . . . 42

5 Number of Births Correlated to Level of Associated CLP Services Provided .......................44

6 Percentages of Subjects' Responses to Survey Items Related to the Availability of Inservice Training Programs in CLP . . . . . . . 45

7 Number of Births Compared to Perceived Need for Inservice Education . . . . . . . . . . . . . . . . . 46

8 Summary of Subjects' Open-Ended Responses Regarding Educational Interests . . . . . . . . . . . . . . . . 47

9 Summary of Subjects' Open-Ended Responses Regarding

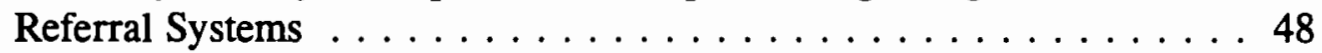

10 Summary of Subjects' Open-Ended Responses Regarding Hospital's Cleft Palate Team . . . . . . . . . . . . . . . 49

11 Summary of Subjects' Open-Ended Responses Regarding Current CLP Inservice Programs . . . . . . . . . . . . . . . . 50

12 Summary of Subjects' Open-Ended Responses Regarding Effects of Managed Health Care . . . . . . . . . . . . . . . 50 


\title{
CHAPTER I
}

\section{INTRODUCTION AND STATEMENT OF PURPOSE}

\author{
Introduction
}

Approximately 4 million babies are born in hospitals throughout the United States each year as estimated by figures provided in the 1996 World Almanac (Famighetti, 1995). Hospital staff members should be equipped with the knowledge and materials needed to care for the immediate needs of neonates, normal or disordered. Cleft lip and palate is one of the most common birth defects found in infants. The incidence of cleft lip with or without palate is reported by Berkowitz (1994) as occurring 1 in every 750 live births in the United States each year. Isolated cleft palate, which is less frequent, occurs approximately 1 in every 2,500 births. Prenatal diagnosis of clefting through techniques such as ultrasound have increased, but it continues to be the norm that clefting is diagnosed at time of delivery. Initial shock is experienced by parents of newborns with cleft lip and/or palate (Drotar, Basklewicz, Irvin, Kennel, \& Klaus, 1975; Strauss, Sharp, Lorch, \& Kahcalia, 1995). For most parents, the orofacial cleft comes as a surprise and the parents are unfamiliar with the defect (MacDonald, 1979). Parents of newborns with cleft lip and/or palate need time to show and share their feelings with health care 
providers and in turn be given information regarding their child's prognosis and future complications (Strauss et al., 1995). Parents must begin to adjust to their newborn's orofacial cleft, the child's special needs, as well as to their own emotions. Shortly after delivery, parents begin the road to understanding the orofacial cleft and its short- and long-term impact. They must quickly face the most basic and potentially complicated task of learning how to sufficiently feed their newborn whose anatomical structures required for feeding, namely the lip and roof of the mouth needed for sucking, are affected. The parents will introduce their new baby to their friends and relatives and must encounter other people's reactions to their newborn's orofacial cleft. Within the first few weeks of their child's life, they will begin planning for surgical repair of the lip if clefting involves the upper lip structure. Infants born with clefting typically require longitudinal special services to treat their dental, surgical, and otologic needs to name but a few. Ideally, the treatment of such patients is directed by a team of professionals, called a cleft palate team or craniofacial team. The cleft palate team concept was formulated over 50 years ago when a dentist, a surgeon, and a speech-language pathologist met to discuss the management of their patients with orofacial clefts (Abdoney, Habal, Scheuerle, \& Rans, 1988). The team has expanded over the years to include other specialists, but the basic nucleus for cleft palate teams remains the same. It is widely accepted that the needs of individuals with clefts are best met by longitudinal team care (ACPA, 1993). 
Diagnostic errors or a failure to recognize and treat the full spectrum of health problems associated with the orofacial cleft is common (ACPA, 1993). Parents of infants with orofacial clefts often suffer from misinformation or delayed information. The nursing methods and procedural duties usually reflect the hospital's nursing training programs and staff management. MacDonald (1979) found that many parents report that the nursing staff was reluctant to listen to them talk about their reactions to the cleft and that, as a result, the severity of the infant's problem became magnified in their minds. This can prevent some parents from bonding with their baby, adjusting to the cleft, and may reinforce the social stigma associated with an orofacial cleft.

The health and welfare of these infants is contingent upon the clinical expertise of those who serve them (ACPA, 1993). Sprietersbach (1961) found that hospitals do not always identify specific professionals to help parents cope with birth defects. The organizational structure of the hospital is such that neonates are usually delivered in the birthing center and/or labor and delivery wing. In most metropolitan centers, the mother and newborn infant are subsequently transferred to the maternity/obstetrics wing within an hour or so after the delivery. It is within the maternity obstetrics nursing wing that families should receive assistance with feeding strategies, bottle or breast, for the neonate who has a cleft, basic information about clefting, as well as receive input regarding referral to a cleft palate/craniofacial disorders team. The responsibility to provide this assistance typically falls on the 
nurse on duty. Unfortunately, actual follow through on these issues may be, at times, inadequate.

\section{Statement of Purpose}

Little research is available regarding initial information and services received by families of newborns with cleft lip and/or palate. Early impressions and assistance with the orofacial cleft have a great impact on the family. MacDonald (1979) reported that misunderstanding and misinformation at this stage is devastating. Parents may accept erroneous facts, such as predictions about speech, language, or neurodevelopmental functioning, as truth for a long while. Care of the infant is directly related to what information and referrals parents have when they leave the hospital. In this study, the current status of initial services provided by hospitals in the State of Oregon to families with newborns with cleft lip and/or palate was investigated utilizing a self-report survey. This study was a duplication of a national survey of nursing care for parents and infants with cleft lip and palate completed over 10 years ago by Scheuerle, Olsen, Guilford, Redding, and Habal (1984). Based on available literature and assumptions regarding status of current health care in Oregon, the following study hypotheses are stated.

1. Twenty-five percent or more of hospitals will report that they fail to provide adequate assistance to parents of newborns with cleft lip and/or palate in 
terms of counseling, training, providing of adaptive feeding equipment and applicable reading materials.

2. Twenty-five percent or more of hospitals will report that they fail to refer families of newborns with clefts to craniofacial specialists.

3. The level of associated services provided to families of new'borns with clefts will be correlated with the number of births that occur at the hospital in which the infant was delivered. Specifically, the fewer the births, the lower the level of associated services.

4. Twenty-five percent or more of hospitals will report that they fail to provide nurses with an inservice education program in cleft lip and/or palate.

5. Twenty-five percent or more of hospitals will report a perceived need for inservice programs focusing on cleft lip and/or palate; furthermore, this perceived need will be related to hospitals' delivery rate. It is hypothesized that, the fewer the number of births, the more likely there will be a perceived need for inservicing.

The following specific research questions were developed:

1. Do hospitals provide assistance to parents of newborns with cleft lip and palate?

2. Do hospitals identify and refer to craniofacial specialists? 
3. Is the level of associated services provided to families of newborns with clefts correlated to the number of births that occur at the hospital in which the infant was delivered?

4. Do hospitals provide nurses and other professionals inservice education program in cleft lip and palate?

5. Do nurses perceive a need for such inservice education programs?

6. Is the perceived need for inservices related to the number of births that occur at the subject's hospital?

\section{Definition of Terms}

The following terms are defined for the purposes of this study:

American Cleft Palate-Craniofacial Association (ACPA): A professional organization founded in 1943. The purpose of this nonprofit multidisciplinary organization is to encourage the improvement of scientific clinical services to persons with cleft palate and associated deformities. The Association publishes journals, disseminates information to parents and the general public, and offers referrals to treatment teams and parent support groups worldwide (ACPA, 1993).

cleft lip and/or palate: An abbreviated way to refer to those individuals with cleft lip, cleft palate, or cleft lip and palate. Also referred to as cleft lip \pm palate. cleft lip: A separation of the two sides of the lip secondary to lack of fusion during embryonic development. The separation often includes the bones of the 
maxilla and/or alveolar ridge. Clefts of the lip do not always extend into the nostril, and in about $10 \%$ of the cases, there are bridges of skin across the cleft. The cleft can be unilateral, occurring on one side of the lip, or bilateral, encompassing both sides of the lip (Moller \& Starr, 1993).

cleft palate: A fissure in the midline of the palate in which the two sides of the palate did not fuse together during embryonic development. The fissure can be complete, extending through both the hard and soft palates. It is often associated with cleft lip (Moller \& Starr, 1993).

cleft palate/craniofacial disorders team: To be recognized by the ACPA as a cleft palate team, the core of the team must meet regularly and include a reconstructive surgeon, dentist, and speech-language pathologist. The principal role of the interdisciplinary team is to provide integrated case management to assure quality and continuity of patient care and longitudinal follow-up. The staff may also include individuals from the following areas of professional practice: anesthesiology, audiology, diagnostic medical imaging/radiology, genetic counseling and/or genetics, medical social work, neurology, neurosurgery, nursing, occupational therapy, ophthalmology, orthodontia, oral surgery, otolaryngology, pediatrics, pediatric dentistry, physical anthropology, physical therapy, prosthodontics, psychiatry, and psychology. Consultation with other professionals may be needed (ACPA, 1993). 
clefting: A division, opening or fissure, that typically originates in embryonic stages (Gorlin, 1993).

craniofacial disorder: Defects or deformities in any part of the face, its skeletal framework, or cranium.

feeding techniques: Potential feeding problems of a neonate with clefting include ineffective suck and difficulty maintaining an adequate labial seal. Special feeding techniques can be utilized to combat these problems. For breast-feeding, a breast pump can be used for initializing the milk flow or expressing milk to be given in a bottle. For bottle-feeding various types of cross-cut nipples and soft pliable bottles can be utilized. The infant should be held upright during feeding and the bottle may need to be squeezed.

incisive foramen: Small circular opening in the maxilla, covered by tissue, that provides a pathway for nerves and vascular system (Moller \& Starr, 1993). isolated cleft lip and/or palate: Clefting in absence of a syndrome (Gorlin, 1993).

labor and delivery wing: The specific area of the hospital that provides the immediate prepartum and childbirth delivery services to women and their families. mandible: A U-shaped bone that makes up the lower jaw. maternity/obstetrics wing: The specific area of the hospital that provides nursing care of women and their families following childbirth prior to discharge. This includes supervision of the mother's care of newborns. Nursing staff in this 
wing typically provide information pertaining to the usual behavior and needs of the newborn, including expected growth and development as well as feeding instruction. maxilla: A paired bone that makes up the upper jaw. orofacial: Pertaining to the mouth and face. palate: The bony and muscular partition between the oral and nasal cavities. philtrum: The infra nasal depression; the groove in the midline of the upper lip.

primary palate: In the early embryo, the mesoderm-filled shelf, formed from the medial nasal process, that anteriorly separates the oral cavity below from the nasal cavities above. It develops into consisting of two medial nasal processes, the philtrum, the upper lip, and the anterior portion of the hard palate up to the level of the incisive foramen (Moller \& Starr, 1993).

secondary palate: The posterior portion of the embryonic palate, which forms the palatal processes of the embryonic maxilla and develops into the remainder of the hard palate and velum (Moller \& Starr, 1993).

syndrome: A group of symptoms and signs which, when appearing simultaneously, form a definite pattern of a specific condition, disease, or abnormality (McWilliams, Morris, \& Shelton, 1990). 


\section{CHAPTER II}

\section{REVIEW OF THE LITERATURE}

The current study investigated the initial nursing care for families of newborns with cleft lip and/or palate in the State of Oregon to determine if current care is adequate. To complete a study of this nature, it is necessary to have an understanding of the initial impact of cleft lip and/or palate and early critical issues for infants with this condition. The optimal care proposed for these children with special needs is also reviewed.

\section{Nature of Clefting}

Cleft lip and/or palate is a congenital birth defect. The primary palate consists of: two medial nasal processes, the philtrum, the upper lip, and the anterior portion of the hard palate up to the level of the incisive foramen. The secondary palate consists of the remainder of the hard palate as well as the soft palate. If during the 4th through 12th week of embryonic development there is a failure of closure of the primary palate and/or a failure of closure of the secondary palate, clefting is said to occur (Gorlin, 1993).

Clefting is considered to be multifactorial in that factors that may result in clefting include genetic and environmental causes (Gorlin, 1993). Wicka and Falk 
(1982) list three possible causes of an orofacial cleft: (a) intrauterine difficulty during the embryonic stages of palate fusion, (b) mechanical obstruction, and (c) genetics. Environmental factors that may possibly cause intrauterine difficulty include malnutrition, a deficiency or excess of Vitamin A, cortisone therapy, insulin injection, rubella, toxemia of pregnancy, anoxia, and radiation. Under the broad umbrella of mechanical obstructions are the following: intrauterine tumors, umbilical cord interference, pressure of the mandible, and failure of the tongue to descend from the nasal cavity. Current belief holds that clefting follows a multifactorial inheritance, which differs from single-gene inheritance, because the risk of recurrence is greater as more family members are affected. In addition, the more severe the defect, the higher the risk is for recurrence (Gorlin, 1993).

\section{Isolated Clefting Versus Clefting as a Component of a Craniofacial Disorder Syndrome}

Isolated clefting means that the person with cleft palate and/or lip is otherwise structurally normal and has no other anomalies. Clefting does not, however, always occur in isolation. A syndrome, in contrast, is a constellation of recognizable differences in the face, cranium, and potentially other body parts such as the heart or kidneys. Cleft palate and/or lip occurs as just one component of over 150 recognized syndromes (Jones, 1988). Jones evaluated 428 patients at the Cleft Palate Program at Children's Hospital and Health Center in San Diego with facial clefts and/or velopharyngeal insufficiency. She found that $29 \%$ had an underlying 
syndrome. The importance of identifying individuals with underlying disorders was stressed because of the potential impact on prognosis and nature and timing of treatment.

A study was conducted examining and reviewing 1,000 patients with clefts of the lip, palate, or both at the Center for Craniofacial Disorders, Montefiore Medical Center in Bronx, New York (Shprintzen, Siegel-Sadewitz, Amato, \& Goldberg, 1985). They found that the majority, $63.4 \%$, of their patients had other anomalies, such as microcephaly or down-slanting palpebral fissures. In addition, half of those patients with other anomalies had identifiable syndromes. This high incidence underlines the fact that patients with cleft lip and/or palate are heterogeneous and treatment and care should correspond according to the implications of their diagnosis. Early, thorough, and careful evaluation of infants with congenital orofacial clefts is imperative to enable detection and management, as needed, of potential associated malformations.

\section{Identification/Diagnosis of Clefting}

There are a number of different methods now available for diagnosing cleft lip \pm palate. The majority of newborns with orofacial clefting are identified at birth (Moller \& Starr, 1993). Transvaginal ultrasonography has been used to detect fetal cleft lip at the early stage of 14 weeks gestation (Bronshtein, Mashiah, Blumenfeld, \& Blumenfeld, 1991). The authors concluded that early second-trimester 
identification of clefting enabled parents to make informed decisions.

Ultrasonography, commonly referred to as ultrasound, is a noninvasive procedure. It involves recording photographically the reflection of ultrasonic sound waves that occur at the boundaries between different tissues within the body in order to give clear outlines of various organs and tissues (Andrews, Anderson, \& Glanze, 1994). Recent use of embryoscopy as a diagnostic procedure was used to diagnosis a cleft lip prenatally at 11 weeks gestation (Dommergues, Lemerrer, Couly, Delezoide, \& Dumez, 1995). Embryoscopy is an invasive procedure in which a fetoscope is brought into contact with the amniotic sac, using ultrasound as a guidance system, in order to observe the embryo through the amniotic sac. The authors caution others to weigh the benefits of early diagnosis against the potential risks of endoscopy.

\section{Parental Reaction to Clefting}

Regardless of when and how the type of craniofacial anomaly and potential associated malformations are diagnosed, family dynamics are typically impacted to some degree by the birth of a child with a facial difference.

The impact of the cleft will depend upon the parents - how much their egos are threatened by a congenital anomaly in their baby and to what extent they have access to and can use various psychological coping mechanisms. (McWilliams et al., 1990, p. 155)

The birth of a child with clefting can enhance the possibility of child abuse, dissolution of a marriage, or poor acceptance of the child (McWilliams, et al., 1990). Parental perspective on the management process of cleft palate and/or lip was 
the focus of a study completed by MacDonald (1979). This study was based on a Boston parents' group of children with clefting over a 6-year period. Results indicated that parents' needs were most apparent at the following critical times: during birth, hospitalization, initial speech development, entry into kindergarten, during pre-adolescence, and adolescence. MacDonald suggested parents look to professionals for information, reassurance, and effective coordination among specialists.

At the newborn stage, professionals sometimes are reluctant to discuss the orofacial cleft or the parents' initial emotional status. The result is the severity of the birth defect and its implications may become even more overwhelming for the parents. Martin (1995) found that the parents' communication and coping abilities are directly affected by the interaction that takes place with health professionals. Prompt referrals, integrated and individualized advice on feeding techniques, and health professionals who took the time to listen were found to give the parents greater confidence and reduce their anxiety. MacDonald (1979) found that parents tended to benefit from written information about orofacial clefting.

To examine the effects of giving birth to a child with a defect, a study was conducted by Clifford and Crocker (1971) involving 100 normal babies and 75 babies with orofacial clefts. They found significant differences in experiences between the mothers of the two groups of babies in two main areas. Mothers of infants with orofacial clefts recalled more difficulty with their pregnancies and 
reported fewer positive changes and more negative changes since the birth of their baby.

Extensive interviews of parents of infants born with cleft lip and/or palate were conducted by Sprietersbach (1961). Although dated, the results of this study identified issues of a pyschosocial nature that continue to be observed at the birth of a newborn with an orofacial cleft. Mothers tend to be concerned for the health and appearance of the child. Fathers want to know the plan for repair of the clefting. Suggested counseling techniques for these families, based on results, include: a unified team approach; constant, repeated interpretation of what is occurring; positive, yet honest, evaluations of the problems by all specialists; and recognition of the parents' role and needs in the habilitation program.

Drotar et al. (1975) found that parental reactions to congenital defects usually follow a predictable sequence of steps. The parents of 20 children with congenital malformations, including cleft palate, were interviewed between 7 days and 60 days after the birth. The five stages that most of the parents experienced were shock, denial, sadness and anger, adaptation, and reorganization. Hesitancy to attach to their newborns was seen in almost all the mothers. This study concluded that to help parents through these stages of grief and adjustment, health professionals should offer advice, support, and counseling. Information from health professionals must be presented clearly and may have to be repeated many times because the initial shock experienced by parents of newborns with orofacial clefting may limit the amount of 
information they can absorb. Effective intervention can reduce some of the pyschosocial difficulties associated with the birth of an infant with orofacial clefting.

A recent study examined the initial perceptions of parents whose children were diagnosed as having a cleft lip and/or palate (Strauss, Sharp, Lorch, \& Kahcalia, 1995). One hundred parents were given a self-administered questionnaire that inquired about parental perspective regarding the initial diagnosis experience. Ninety-six percent of the parents received the diagnosis from the physician. Results indicated that parents wanted more time to show and share their feelings with the physician, they wished the physician had exhibited more caring and certainty, and they desired a support contact with other parents who had undergone a similar experience.

There are a number of factors that affect how parents of newborns with orofacial clefting respond to their infant's diagnosis of cleft lip \pm palate and the challenges that follow. Their internal psychological coping mechanisms and established family dynamics have direct bearing on how they react. The communication and coping abilities of parents of newborns with clefting are susceptible to failure initially after the infant's birth. The parents' interactions with health care professionals have a significant impact on the family. Health care professionals should strive to take time to listen to the parents, give prompt referrals, integrated and individualized advice regarding feeding and other issues, a 
unified team approach, repeated interpretation, and recognition of the parents' role and needs (Strauss et al., 1995; MacDonald, 1979; Sprietersbach, 1961).

\section{Overview of Early Issues: Increased Risk of Weight Loss, Associated Anomalies, and Need for Surgery}

There are inherent risks associated with clefting, especially in the initial stages. Early critical issues for the infant with clefting include feeding difficulty with malnutrition risk, possible associated malformations, and need for lip and/or palatal surgery. Assisted by parental involvement, medical management of the infant with an orofacial cleft must be done with an individualized and integrated approach.

Feeding difficulties are typical for infants with cleft lip \pm palate. Oftentimes, they are unable to build up adequate suction secondary to the open communication between the oral and nasal cavities. This decompresses the negative pressure normally created in sucking (Brine et al., 1994). This inadequate suck can result in prolonged feeding times, nasal regurgitation, and possible aspiration. The infant then becomes at risk for inadequate nutrition during this critical period for growth. Brine et al. reported that inadequate nutrition at this time can result in growth failure, impaired immune function, major organ dysfunction, complications in recovery from surgery, and behavior problems. It is critical that the growth and development of infants with clefting be consistently monitored.

As stated previously, there is a high risk for infants with orofacial clefting to have an underlying syndromic disorder. Jones (1988) found that $29 \%$ of the patients 
with facial cleft or velopharyngeal insufficiency had recognized syndromes.

Shprintzen et al. (1985) found that approximately $30 \%$ of their patients with clefts of the lip, palate, or both had identifiable syndromes, sequences, or associations. The implications of a syndrome have direct bearing on genetic counseling, speech development, altered neurodevelopmental function, midface growth, dental development, and the timing and nature of surgical reconstruction (Jones, 1988).

Cleft lip repair is usually done within the first 6 months of life or as soon as it is safe for the infant (ACPA, 1993). It is imperative that the family become acquainted and established with a surgeon as soon as possible because of the imminent surgery and the multiple surgical procedures required to repair the orofacial clefting. The craniofacial or plastic surgeon typically works in conjunction with a craniofacial disorder team.

\section{Intervention and Cleft Palate/Craniofacial Team Management}

For optimal results the development of the child with cleft lip \pm palate should be monitored by the interdisciplinary team (ACPA, 1993). In the first year of life close attention should be given to the following: (a) height, weight gain, nutrition, feeding disorders, and growth; (b) continuity of routine pediatric care, including immunizations; (c) motor, cognitive, and social development; (d) speech and language development; (e) otologic health; (f) hearing status; (g) parent-child adaptation, parental skills, behavior management, and nurturance; (h) the condition 
of the developing dentition and supporting tissues, with counseling regarding early oral hygiene; (i) the physical status of the child as it pertains to readiness for surgical management; and (j) modifications to the treatment plan as necessitated by any additional information regarding more complete genetic/dysmorphologic diagnoses or changes in the family status. Continued longitudinal care helps to assure quality care for the family and patient.

The management of cleft lip \pm palate is complex and requires specialties from various disciplines to deal with these diverse issues. A document published by the American Cleft Palate-Craniofacial Association in 1993 (ACPA) affirms that the craniofacial interdisciplinary team is the best way to meet the special health care needs of children with craniofacial anomalies. At the core of the team is a speechlanguage pathologist, dentist, and oral surgeon. Team members include professionals from the areas of anesthesiology, audiology, diagnostic medical imaging/radiology, genetic counseling, genetics/dysmorphology, neurology, nursing, ophthalmology, oral and maxillofacial surgery, orthodontics, otolaryngology, pediatrics, pediatric dentistry, physical anthropology, plastic surgery, prosthodontics, psychiatry, psychology, social work, and speech-language pathology. All professionals involved with the team are required to have proper training and experience with craniofacial anomalies. Integrated case management is the responsibility of the interdisciplinary team in order to maintain quality care and continuity. 
Abdoney et al. (1988) identified and described multidisciplinary craniofacial teams in Florida. The teams provide second opinions, diagnosis, evaluation, planning of treatment, and professional continuing education. The team is described as a group of specialists who work together and exchange specific knowledge from their respective fields to provide the best outcome for the patient with cleft lip \pm palate.

To be recognized by the American Cleft Palate-Craniofacial Association, a reconstructive surgeon, dentist, and speech-language pathologist must meet on a regular basis to form the core of the craniofacial team (Moller \& Starr, 1993). The team must appoint a person to direct and coordinate team activities. The role of the interdisciplinary team is to consult with the family regarding treatment and/or carry out that treatment to provide the best possible service to the patient.

\section{Parental Involvement with the Cleft Palate Team}

From the moment of first contact with families of newborns with cleft lip and/or palate, the greatest effort should be made to help the family adjust to their newborn (ACPA, 1993). In addition, the family should be given information about recommended treatment procedures, options, risk factors, benefits, and costs. The family should be encouraged to participate and collaborate in the planning of treatment for their child. Early referral of a child to a cleft palate/craniofacial team can increase the likelihood of these to occur. 
Moller and Starr (1993) indicated that there must be effective communication between the interdisciplinary craniofacial team and the family with regard to the treatment plan. Ultimately, it is the family that decides to proceed or discontinue with the treatment plan. Aspinall (1995) outlined suggestions for all medical professionals to follow when dealing with the family to make decisions about medical treatment. As professionals one should: (a) listen to and validate a family's opinions and observations before launching into your own, (b) spend some time looking at personal biases, (c) try to reconcile the difference between what the family says and what the family does, and (d) maintain perspective.

Utilizing family members as team participants in the cleft palate team is becoming more of a focus. A recent study by Pannbacker and Scheuerle (1993) specifically looked at the degree of involvement of the family in cleft palate treatment. Surveys were distributed to families with a child having an orofacial cleft in Florida, Louisiana, Minnesota, and Pennsylvania. Over half the surveys were returned for analysis. Cleft palate team services were used by $89 \%$ of the families. The majority of parents were satisfied with their involvement on the cleft palate team. However, $79 \%$ of the parents would like more information about orofacial clefts. 


\section{Early Care of Individuals with Clefts}

A survey of 100 hospitals in the United States was undertaken by Scheuerle et al. (1984) approximately 10 years ago. The two hospitals that had the largest percentage of delivering babies in each of the 50 states were sent a survey. From a pool of 100 potential hospitals, 52 hospitals responded. These 52 hospitals represented all geographic areas of the United States. Ninety-four percent of the responding hospitals had had babies delivered with orofacial clefting within the past year. The response from hospital personnel showed deficiencies in initial nursing care services to parents of newborns with cleft lip \pm palate. Only $38 \%$ offered training programs for parents. Referrals to cleft lip \pm palate parent support groups were made in $23 \%$ of the hospitals. Seventy-one percent of the responding hospitals provided reading materials regarding clefting to the parents. Parents were provided with a list of support agencies in $62 \%$ of the hospitals. Identification and referrals to specialists for families of newborns with clefts was found in $50 \%$ of the hospitals. Forty percent of these surveyed hospitals reported that they had local cleft palate/craniofacial teams. Nursing education programs focusing on issues related to clefting were found in less than half of these hospitals. Scheuerle et al. suggested that experienced cleft palate teams should provide educational information to hospital nursing staffs to bridge this gap. Furthermore, this information should be included as a component of the curriculum in nursing education at the college/university level. 
Based on information obtained from respondent hospitals in Scheuerle et al.'s national survey (1984) it was found that assistance and training for new parents of infants with cleft lip and/or palate provided by hospital staff are inadequate. Overall, information regarding clefting and referrals to cleft palate-craniofacial teams were not given to parents during their initial stay at the hospital. The survey findings indicated hospital staff desire more inservice nursing education about orofacial clefts. Scheuerle et al. concluded that it is the responsibility of the cleft palatecraniofacial teams to create and provide inservice nursing education on the care of new parents of infants with cleft lip and/or palate.

There are currently four agencies providing interdisciplinary care within the State of Oregon. It is unclear what role, if any, cleft palate/ craniofacial teams of these agencies have served in nurses' education in metropolitan and rural hospital settings. Information related to inservice education programs in the nursing care of parents of children with cleft lip \pm palate within the State of Oregon is unavailable. Furthermore, information provided to families by nurses in the maternity wing of a hospital is unknown. Clarification regarding the status of these issues could help determine if improved care of infants with their clefts and their families via increased education of the initial professionals who serve them would be of benefit. 


\section{CHAPTER III}

\section{METHODS}

This study used a self-report survey to yield information regarding the current status of initial services provided by hospitals in the State of Oregon to families with newborns with cleft lip and/or palate. This study involved research using survey procedures and therefore fell into one of the categories of studies exempt from review by Portland State University's Human Subjects Research Review Committee. The study was in large part, a duplication of an earlier national survey of nursing care for parents and infants with cleft lip and palate (Scheuerle et al., 1984). Unlike the Scheuerle et al. study which obtained a sampling of responses at a national level from the two hospitals in each state with the highest birth rate, the current study solely surveyed Oregon hospitals, with both high and low birth rates. This research study sought to address the following questions within the State of Oregon:

1. Do hospitals provide assistance to parents of newborns with cleft lip and palate?

2. Do hospitals provide identification and referral to craniofacial specialists? 
3. Is the level of associated services provided to families of newborns with clefts correlated to the number of births that occur at the hospital in which the infant was delivered?

4. Do hospitals provide nurses and other professionals inservice education programs in cleft lip and palate?

5. Do hospital staff perceive a need for inservice education programs?

6. Is the perceived need for inservices related to the number of births that occur at the subject's hospital?

\section{Subjects}

\section{Subject Selection}

When an infant is born, it is primarily the nurse(s) on duty who interact with the mother and family on a consistent basis. Therefore, it is the nurse(s) who provide the majority of initial care to families with newborns with cleft lip \pm palate. Similar to the Scheuerle et al. study (1984), the Directors of Nursing and/or Directors of Inservice Education at hospitals were the intended subjects for this study because they oversee and manage the nursing staff and are well-versed with the nursing procedures and duties at their respective hospitals.

\section{Subject Identification and Recruitment}

The intended subjects of this study were Directors of Nursing and/or Directors of Inservice Education at hospitals located throughout the State of Oregon. 
To determine potential subjects and assist with recruitment, hospitals were selected from the American Hospital Association Guide to the Health Field, 1995 edition. This guide includes hospitals registered by the American Hospital Association and osteopathic hospitals listed by the American Osteopathic Association. An institution is registered by the American Hospital Association as a hospital if it is accredited as a hospital by the Joint Commission on Accreditation of Healthcare Organizations. An institution is also registered if it is certified as a provider of acute services under Title 18 of the Social Security Act. All hospitals included in the study are to offer obstetrics services and deliver more than 40 babies each year. Fifty medical hospitals in Oregon met these criteria (Appendix A). The Director of Nursing and Director of Inservice Education at each institution were mailed a cover letter (Appendix B), consent form (Appendix C), and questionnaire (Appendix D) requesting their participation in this survey study. Two copies of the study survey were sent to each institution; one sent to the Director of Nursing and one sent to the Director of Inservice Education. Each copy was coded by number and letter as in $1 \mathrm{a}$ and $1 \mathrm{~b}$ to allow institution reliability, increase likelihood of response, and allow elimination of duplication of responses. In the case where two different study surveys were sent back from the same institution the first one received was used in data analysis. In addition, a follow-up postcard was used as a reminder 3 weeks after the initial mailing to those hospitals who had not responded (Appendix E). 


\section{Subject Consent}

Subjects agreed to participate in the study by signing a consent form (Appendix C) that accompanied the mailing of the study survey. This consent form meets the standards required by the Human Subjects Research Review Committee at Portland State University.

\section{Response Rate}

Twenty-eight study surveys from 26 different medical hospitals were completed and returned out of the 100 surveys mailed to 50 medical hospitals in the State of Oregon that met this study's criteria. This results in a response rate of $52 \%$ for study participation. Twenty-six subjects responded to the initial survey mailing and two subjects responded to the follow-up postcard sent as a reminder 3 weeks after the initial survey mailing.

\section{Subject Distribution}

Two surveys were sent to each hospital, one addressed to the Director of Nursing; the other addressed to the Director of Inservice Education. More respondents were from Nursing (71.4\%) than Nursing Education (10.7\%). Respondents also included the Director of Maternal/Child Services, two SpeechLanguage Pathologists, the Clinical Director of a cleft lip \pm palate team/ Developmental Pediatrician, and an Operations Assistant Administrator. Table 1 summarizes distribution of respondent type according to job title. 
TABLE 1

Distribution of SubJects ACCoRding to Job Title $(N=28)$

\begin{tabular}{|l|c|c|}
\hline Job Title & Number & Percent \\
\hline $\begin{array}{l}\text { Obstetrics Nursing (includes OB Coordinator, OB } \\
\text { Manager, OB Charge Nurse) }\end{array}$ & 13 & 46.4 \\
\hline $\begin{array}{l}\text { General Nursing (includes Director of Nursing, Chief of } \\
\text { Nursing, Manager of Nursing) }\end{array}$ & 7 & 25.0 \\
\hline Nursing Educator/Education Specialist & 3 & 10.7 \\
\hline Director of Material/Child Services & 1 & 3.5 \\
\hline Clinical Director of CLP Team/Developmental Pediatrician & 1 & 3.5 \\
\hline Operations Assistant Administrator & 1 & 3.5 \\
\hline Speech-Language Pathologist & 2 & 7.1 \\
\hline
\end{tabular}

\section{Demographics of Responding Subjects' Hospitals}

Responding hospitals varied according to: (a) delivery rate, (b) geographic area of Oregon, (c) size of city in which their hospital was located, and (d) number of infants delivered with orofacial clefts during the past year. Hospital delivery rate ranged from low, delivering 47 newborns per year, to high, delivering 3,362 newborns per year. All geographic areas of Oregon were represented in this survey. Hospitals were located in the following geographic regions: Eastern Oregon represented by Ontario, Enterprise, Baker City, Hermiston, and Burns; from Central Oregon were Madras and Redmond; Southern Oregon was represented by Coquille and Ashland; cities along the coast included Seaside, Tillamook, Lincoln City, Newport, and Florence; and from Western Oregon were Portland, Corvallis, 
Lebanon, Salem, and Hood River. Subjects who responded worked at hospitals located in different size cities. Hospitals can be described as located in urban versus rural settings.' Urban is defined, in U.S. census use, as a city consisting of at 50,000 inhabitants. Twelve hospitals came from cities that met this urban criteria, while 24 of the responding hospitals were located in rural settings.

Eight of the 26 (30.7\%) responding hospitals reported they had infants born with orofacial clefts during the past year. Of these eight hospitals, the number of infants with orofacial clefts born in each hospital ranged from 1 to 10 .

\section{Measures and Procedures}

Two sets of a cover letter, consent form, and a self-addressed stamped return envelope were mailed with the survey to 50 Oregon hospitals that met the study's criteria for inclusion. To increase response rate, one set was addressed to the Director of Nursing; the other was addressed to the Director of Inservice. Surveys were coded, for example 1a and $1 \mathrm{~b}$, to enable the principal investigator to know when 2 surveys were completed and returned from different personnel at the same hospital. Directors of Nursing and Directors of Inservice Education at each hospital were asked to complete the survey and return it by a specified date, approximately 2 weeks after its initial mailing. They were cued in the cover letter to complete the survey only once if they serve a dual role as Director of Nursing and Director of Inservice Education. To further enhance the response rate, the cover letter notified 
participants that an abstract of the study's results would be sent to all participants expressing interest if they returned their survey. No monetary awards for participants were provided. In addition, a follow-up postcard was used as a reminder 3 weeks after the initial mailing to those hospitals which had not responded (Appendix E).

\section{Survey Tool}

The survey tool will first be described and then a description of how the survey tool was used to answer this study's research questions will follow. The survey of nursing care for parents of infants with cleft lip and palate created for the original Scheuerle et al. (1984) study was utilized with minor modifications for this study. Table 2 lists survey questions; Appendix D contains a copy of the actual survey format.

The survey contained 12 forced choice (yes/no) items and 5 open-ended descriptive information items. Survey item 1a asked if there was an incidence of cleft lip/palate in the hospital in the past year. Survey item $1 \mathrm{~b}$ was used to elicit information regarding the number of infants born with cleft lip \pm palate at their hospital over the past year. Survey item 2a inquired if postnatal staff were given training in the care and management of infants with cleft lip \pm palate. Survey item $2 \mathrm{~b}$ asked respondents if they perceived that inservice education programs would be beneficial for nursing staff on the care of infants with cleft lip \pm palate. Survey item 3 asked if adaptive feeding equipment was available for the family to use to feed 
Table 2

\section{List of Questionnaire Survey Items}

\begin{tabular}{|c|c|}
\hline $1 \mathrm{a}$ & Has there been an occurrence of cleft lip \pm palate births in your hospital during the past year? \\
\hline $1 \mathrm{~b}$ & any? \\
\hline $2 a$ & Are your postnatal staff given training in the management of cleft lip \pm palate infants? \\
\hline $2 \mathrm{~b}$ & $\begin{array}{l}\text { Do you feel that an inservice education program would be beneficial for your nursing staff or } \\
\text { other professionals in your hospital on the care of infants with cleft lip } \pm \text { palate? }\end{array}$ \\
\hline 3 & $\begin{array}{l}\text { Does your hospital have adaptive feeding equipment readily available for the newborn with } \\
\text { cleft lip } \pm \text { palate? }\end{array}$ \\
\hline 4 & $\begin{array}{l}\text { Does your hospital provide training or education programs for new parents of a newborn with } \\
\text { cleft lip } \pm \text { palate? }\end{array}$ \\
\hline 5 & $\begin{array}{l}\text { Does your hospital provide reading materials and/or a list of suggested reading materials for } \\
\text { new parents of an infant with cleft lip } \pm \text { palate? }\end{array}$ \\
\hline 6 & $\begin{array}{l}\text { Are there trained professionals on staff at your hospita } \\
\text { with craniofacial anomalies? }\end{array}$ \\
\hline 7 & $\begin{array}{l}\text { Does your hospital provide parent } \\
\text { care and management of infants w }\end{array}$ \\
\hline 8 & $\begin{array}{l}\text { Are there trained professionals on staff at your hos } \\
\text { cleft lip } \pm \text { palate? }\end{array}$ \\
\hline 9 & Are referrals to Cleft Lip/Palate teams given to parents? \\
\hline 10a & $\begin{array}{l}\text { Is there a Cleft Lip/Palate parent group for parents } \\
\text { area? }\end{array}$ \\
\hline $10 \mathrm{~b}$ & If yes, are referrals to these Cleft Lip/Palate parent groups given to the parents? \\
\hline 11 & $\begin{array}{l}\text { Are there inservice education programs on the care of infants with cleft lip } \pm \text { palate available } \\
\text { for nurses? }\end{array}$ \\
\hline 12 & $\begin{array}{l}\text { If such a workshop were to be presented to your staff what particular area in relation to cleft } \\
\text { lip } \pm \text { palate would you like to see presented? Please describe. }\end{array}$ \\
\hline 13 & $\begin{array}{l}\text { Describe your current referral system for parents and infants of cleft lip } \pm \text { palate to other } \\
\text { professionals/specialists. }\end{array}$ \\
\hline 14 & Describe the members of the local Cleft Palate Team(s) that your hospital utilizes. \\
\hline 15 & Describe current inservice education for nurses on the topic of cleft lip \pm palate. \\
\hline 16 & $\begin{array}{l}\text { Describe how managed health care has affected the management of care for infants born } \\
\text { cleft lip } \pm \text { palate. }\end{array}$ \\
\hline
\end{tabular}


their newborn with orofacial clefting. Survey item 4 asked if the hospital provided training or educational programs for new parents of infant with cleft lip \pm palate. Survey item 5 measured if hospitals provided educational reading materials and/or a list of suggested reading materials for new parents of an infant born with orofacial clefting. Survey item 6 asked if hospitals had professionals trained to work specifically with craniofacial anomalies on site. Survey item 7 asked respondents if their hospitals provided parents with a list of professionals who specifically work in the care and management of infants with clefting. Survey item 8 asked if the hospitals provided trained professionals to counsel parents of infants with cleft lip \pm palate. Survey item 9 asked if hospitals referred parents to cleft palate-craniofacial teams. Survey item 10a asked hospitals if there were any cleft lip and palate parent support groups in their area. Survey item $10 \mathrm{~b}$ asked if hospitals referred parents to local cleft lip and palate parent support groups. Survey item 11 asked if inservice education programs regarding cleft lip \pm palate were provided to the hospital nursing staff.

Items 12 through 16 were open-ended questions. They sought to elicit information about educational interests, referral systems, current inservice education programs, and effects of managed care. They were used to obtain written explanations and descriptions to elaborate on responses to the forced choice items and to elicit concerns regarding issues related to cleft lip and palate management. 
Use of Survey Tool to Respond to Research Questions

Research Question 1 asked, "Do hospitals provide assistance to new parents of infants with cleft lip \pm palate?" Research Question 1 was answered by survey items $3,4,5,8,10 \mathrm{a}$, and $10 \mathrm{~b}$ which referred to issues regarding types of assistance offered by the hospital. Research Question 2 asked, "Do hospitals identify and refer families to craniofacial specialists?" Research Question 2 was answered by survey items 6,7 , and 9 which asked about identification and use of specialists in the care of the child and the family. Research Question 3 asked, "Is the level of associated services provided to families of newborns with cleft correlated to the number of births that occur at the hospital in which the infant was delivered?" Survey items 3 through 9 which dealt with care and treatment given to families of newborns with clefts were used to answer research Question 3. Survey items 2a and 11 allowed research Question 4 which asked, "Do hospitals provide inservice education programs in cleft lip \pm palate?" to be addressed by asking about training and inservice education provided to nursing and other professional staff. Research Question 5a, "Do hospital staff perceive a need for inservice education programs?" was answered by survey item $2 b$. Research Question $5 b$ targeted the relationship between perceived need for inservices and number of births at the respondent's hospital. Research Question 5b was answered by comparing the number of births at the respondent's hospital to the respondent's reported perceived need for inservicing which was obtained via response to item $2 \mathrm{~b}$. 


\section{Survey Response Reliability}

Every accredited Oregon hospital that delivered more than 40 babies per year was sent two questionnaires, one addressed to the Director of Nursing and the other addressed to the Director of Inservice Education. Surveys were coded using numbers 1 to 100 and letters a and b. For example, the Director of Nursing at a hospital received survey coded 3a while the Director of Inservice Education at the same hospital was to receive a study survey coded $3 \mathrm{~b}$. Survey response reliability per institution was computed for those hospitals in which both surveys were completed and returned by separate hospital personnel. The first survey received through the mail was used in data analysis when two surveys were completed and returned from a single hospital. There were only 2 hospitals in which 2 different subjects within the same hospital each returned a survey. This small sample size $(n=2)$ made using any traditional reliability measures unstable. To test whether answers to this survey questionnaire were consistent and accurate, interrater reliability was measured by testing the probability that 2 respondents from the same institution would have exactly the same answers to the 12 forced-choice questions. Interrater reliability within hospitals was found to be .75 and .83 respectively for each of the 2 hospitals on exact responses across survey items. This indicated reasonable reliability for the study survey. 
Data Analysis

\section{Data Coding}

Data were collected from 28 Nursing and Inservice Education Directors at 26 Oregon hospitals who responded to the questionnaire. Data were transferred from the questionnaires to grid sheets and recorded according to item numbers. Survey Items 1 through 11 were forced choice questions. Respondents were given the response options of yes, no, or I don't know. The study's research questions were answered, in part, by computing the percentages of the yes and no answers for these forced choice survey items. For information purposes only, percentages were also calculated for the response option of I don't know or if a respondent gave no response by leaving the answer blank. The data coding (Appendix F) assigned values to the response options of yes and no. Answers marked yes were coded 1 and answers marked no were coded 0 . The data coding was used: (a) to determine interrater reliability within a hospital and (b) determine level of overall care hospitals provided to parents of infants with orofacial clefting needed in answering Research Question 3.

\section{Descriptive and Quantitative Analysis}

Questionnaires were completed and returned. The data were analyzed and presented using descriptive and quantitative techniques. Responses enabled determination of: (a) response rate; (b) subject distribution according to job title; (c) 
determination of demographics of responding hospitals according to annual delivery rates, geographic regions within the State of Oregon, size according to its rural or urban location; and (d) determination of whether the hospital had infants born with orofacial cleft during the past year and, if yes, determination of the number of infants born with orofacial cleft in each hospital.

Percentages of responses to survey items $3,4,5,8,10 \mathrm{a}$, and 10b were calculated and examined to investigate if assistance is provided to parents of newborns with clefts in terms of adaptive feeding equipment, parent training programs, educational reading materials, on-site counseling, and parent support groups. Percentages of responses to survey items 6, 7, and 9 were calculated to study if hospitals identify and refer to craniofacial specialists when an infant is born with orofacial clefting.

Spearman Rho Rank was used to determine if there was a correlation between the number of births delivered at a hospital and the number of total positive responses from survey items 3 through 9 , reflecting overall care and treatment given to families with infants born with orofacial clefting. Subsequently Chi Square analysis was performed by dividing the responding hospitals into two groups, those delivering over 300 babies and those delivering under 300 babies, and dividing the total score received for positive responses across survey items 3 through 9 into two groups, high and low to further examine of the correlation between number of births and level of services provided. 
Percentages of responses to survey items $2 a$ and 11 were calculated and examined to determine if hospitals provide their staff with education programs in cleft lip and palate in terms of training and inservicing. Percentages of responses for other select survey items were calculated and examined to study hospital personnel's perceived need for inservice education programs in the management of cleft lip \pm palate as well as to further examine the pattern between hospital personnel's perceived need for inservicing and their hospital's birth rate.

Descriptive analysis techniques were used to describe subjects responses to survey open-ended questions that inquired about educational interests, referral systems, current inservice programs, and effects of managed care. 


\section{CHAPTER IV}

\section{RESULTS AND DISCUSSION}

\section{Results}

The purpose of this study was to obtain information regarding the level of assistance and training parents of newborn infants with clefts are provided by hospital staff within the State of Oregon. Twenty-eight professionals from 26 different hospitals throughout Oregon completed and returned a 16-item self-report survey that elicited information about level and type of assistance provided to families of newborns with clefts as well as information regarding perceived need for inservicing, impact of managed care, and referral systems. Study limitations will be discussed, followed by presentation of this study's findings.

\section{Study Limitations}

There were a number of limitations inherent in this self-report survey study. First, since a self-report survey was utilized, data obtained are reliant upon the honesty and accuracy of the respondents. Due to the fact that objective measures were not used, data could possibly be skewed and not reflect what is actually occurring at hospitals. The response rate was $52 \%$ leaving $48 \%$ of the Oregon accredited hospitals unaccounted for. It is not known how almost half of Oregon 
hospitals would have responded. There is the possibility of a biased sample.

Individuals who responded may be ones who are currently concerned about the level of assistance their hospital is currently able to provide to families of newborns with clefts. An additional limitation is that some of the subjects' responses to the openended survey questions were difficult to interpret. A live interview format would have allowed for elaboration and clarification of responses. In light of these limitations, the study results are presented.

\section{Nursing Assistance to Parents of Newborns with Clefts}

Research Question 1 asked "Do hospitals provide assistance to new parents of infants with cleft lip and palate?" Assistance, per the Scheuerle et al. (1984) study, involves provision of adaptive feeding equipment, appropriate reference materials, and referral to appropriate support groups. Data collected from subjects' responses to 6 survey items were analyzed to answer this question. Survey items used to gauge if there was nursing assistance to parents of newborns with clefts included: item 3 which inquired if adaptive feeding equipment was available for the family to use to feed their newborn; item 4 which assessed if the hospital provided training or education programs for parents regarding clefting; item 5 which sought to determine if hospitals provided educational reading materials and/or a list of suggested reading materials regarding cleft lip \pm palate for new parents; item 8 which asked if there were trained on-staff hospital professionals to counsel parents of infants with clefting, and survey items $10 \mathrm{a}$ and $10 \mathrm{~b}$ which ask if there were cleft lip and/or palate 
parent support groups in the area and if parents were referred to these area support groups. Table 3 summarizes percentages of subjects' responses to questionnaire items related to study Question 1. Responses indicated that the most common parental assistance offered by hospitals was adaptive feeding equipment to use, available in $65.4 \%$ of the hospitals. Only $30.8 \%$ of hospitals offered training or education programs for new parents of infants with cleft lip \pm palate. Half of the respondents indicated that their respective hospital offered reading materials and/or a list of suggested reading materials for new parents of an infant with cleft lip and/or palate. Sixty-nine percent of hospitals did not provide trained professionals to

\section{TABLE 3}

Percentages of SubjeCts' Responses to Survey Items Related to NuRsing Assistance to NeWBorns with Clefts $(N=26)$

\begin{tabular}{|l|c|c|c|c|}
\hline & \multicolumn{4}{|c|}{ Response (\%) } \\
\hline Survey Item & No & Yes & $\begin{array}{c}\text { Don't } \\
\text { Know }\end{array}$ & $\begin{array}{c}\text { No } \\
\text { Response }\end{array}$ \\
\hline $\begin{array}{l}\text { 3. Available adaptive feeding } \\
\text { equipment }\end{array}$ & 19.2 & 65.4 & 7.7 & 7.7 \\
\hline 4. Parent training programs & 57.7 & 30.8 & 3.8 & 7.7 \\
\hline $\begin{array}{l}\text { 5. Education reading materials } \\
\text { offered }\end{array}$ & 38.5 & 50.0 & 3.8 & 7.7 \\
\hline $\begin{array}{l}\text { 8. On staff professionals trained to } \\
\text { counsel in CLP }\end{array}$ & 69.2 & 15.4 & 7.7 & 7.7 \\
\hline $\begin{array}{l}\text { 10a. Area cleft lip } \pm \text { palate parent } \\
\text { support groups }\end{array}$ & 26.9 & 19.2 & 46.2 & 7.7 \\
\hline $\begin{array}{l}\text { 10b. Referrals to parent support } \\
\text { groups }\end{array}$ & 15.4 & 19.2 & 7.7 & 38.5 \\
\hline
\end{tabular}


counsel parents of infants with orofacial clefts. There were $19.2 \%$ of the hospitals that indicated they had cleft lip and/or palate parent support groups in the area and all $19.2 \%$ of these hospitals reported they referred parents to these support groups.

\section{Nursing's Referral of Newborns with Clefts}

Research Question 2 asked "Do hospital nurses identify and refer craniofacial disorders specialists to these parents?" Individuals with clefts are best served by professionals who have training and sufficient experience in working with their special health care needs (ACPA, 1993). Data collected from subjects' responses to the following survey items were utilized to answer this question: item 6 asked if hospitals have professionals trained to work specifically with craniofacial anomalies on site; item 7 asked if hospitals provided parents with a list of professionals who specifically work with the care and management of infants with cleft lip \pm palate; and item 9 asked if hospitals referred parents to cleft palate-craniofacial teams. Table 4 summarizes percentages of subjects' responses to survey items related to study Question 2. Only 7.7\% of the respondents indicated that they had on-site professionals trained to work specifically with craniofacial anomalies. Parents were provided with a list of professionals who specifically work with the care and management of cleft lip \pm palate at $46.2 \%$ of the responding hospitals. Half of the hospitals referred parents to cleft palate-craniofacial teams. 
TABLE 4

PERCENTAGES OF SUBJECTS' RESPONSES TO SURVEY ITEMS RELATED TO NURSING'S REFERRAL OF NEWBORNS WITH CLEFTS $(N=26)$

\begin{tabular}{|l|c|c|c|c|}
\hline & \multicolumn{4}{|c|}{ Response (\%) } \\
\hline Survey Item & No & Yes & $\begin{array}{c}\text { Don't } \\
\text { Know }\end{array}$ & $\begin{array}{c}\text { No } \\
\text { Response }\end{array}$ \\
\hline $\begin{array}{l}\text { 6. Availability of on-site trained CLP } \\
\text { professionals }\end{array}$ & 76.9 & 7.7 & 7.7 & 7.7 \\
\hline $\begin{array}{l}\text { 7. Parents provided with list of CLP } \\
\text { professionals }\end{array}$ & 30.8 & 46.2 & 15.4 & 0.0 \\
\hline $\begin{array}{l}\text { 9. Referrals to cleft palate- } \\
\text { craniofacial teams }\end{array}$ & 19.2 & 50.0 & 23.1 & 7.7 \\
\hline
\end{tabular}

Research Question 3 asked, "Is the level of associated services provided to families of newborns with clefts correlated to the number of births that occur at the hospital in which the infant was delivered?" Research Question 3 was answered by use of Spearman Rho and Chi Square analyses. Spearman Rho Rank order correlation determined the extent of the relationship between the number of infants delivered in the hospital and the hospital's reported level of associated services, which was the total positive responses from items 3 through 9 . The correlation coefficient was found to be moderately positive $(r=.46)$. A test of significance was not completed for this $r$ value. Rather, Chi Square analysis was used to further examine this correlation. Chi Square analysis required: (a) calculation of the associated level of services provided and (b) separation of hospitals into many and few birth rate groups. Survey items 3 through 9 directly reflect overall care and 
treatment of families with infants demonstrating orofacial clefting. The level of associated services was determined by determining how many yes responses to survey items 3 through 9 a hospital answered, with a maximum of 7 yes responses. Namely, this is the total positive responses for survey items 3 through 9 . The score each hospital received reflected how many associated services were available to families with infants born with cleft lip \pm palate out of the 7 services inquired about in survey items 3 through 9 . The possible range of scores was 0 to 7 , with 0 indicating no associated services provided and 7 indicating high level of associated services provided. Number of births were considered either few (less than 300 births per year) or many (equal to or more than 300 births per year). Data were then compiled into a contingency table for cross tabulation. Table 5 summarizing the Chi Square analysis reveals that the level of associated services depends on the number of births delivered by a hospital because almost all respondents from hospitals with few births (less than 300 ) received low scores, while hospitals with many births (equal to or more than 300 ) were split almost equally. The significance of this relationship was found to be statistically significant $(p=.011<.05)$. This indicated that the level of associated services provided by a hospital was related to the hospital's birth rate. A low level of services is provided in hospitals with low delivery rates. Levels of services in hospitals with high birth rates are more variable. Some high birth rate hospitals provide high level of associated services; other high birth rate hospitals provide low level of associated services. 
TABLE 5

NUMBER OF BIRTHS CORRELATED TO LEVEL OF ASSOCIATED CLP SERVICES PROVIDED $(N=26)$

\begin{tabular}{|l|c|c|}
\hline & $\begin{array}{c}\text { Few Births } \\
(<300 / \text { year })\end{array}$ & $\begin{array}{c}\text { Many Births } \\
(>300 / \text { year })\end{array}$ \\
\hline $\begin{array}{l}\text { Low level of CLP services provided } \\
\text { (score of 0 - 3) }\end{array}$ & 12 & 6 \\
\hline $\begin{array}{l}\text { High level of CLP services provided } \\
\text { (score of 4 - 7) }\end{array}$ & 1 & 7 \\
\hline
\end{tabular}

\section{Availability of Inservice Education Programs in CLP}

Research Question 4 asked “Do hospitals provide nurses with inservice education programs in cleft lip and palate." Data collected from subjects' responses to the following survey items were studied to answer this question: item 2a asked if postnatal staff were given training, at the time of their hire, in the care and management of infants born with orofacial clefting and item 11 asked if hospitals provide inservice education programs for nursing staff regarding cleft lip \pm palate. Table 6 summarizes percentages of subjects' responses to these survey items. Only $26.9 \%$ of respondents indicated that their postnatal staff is given training in the management of the cleft lip \pm palate. Even fewer (15.4\%) offer inservice education programs on the care of infants with orofacial clefting. 
TABLE 6

PERCENTAGES OF SUBJeCTS' RESPONSES TO SURVEY ITEMS RELATED TO THE AVAILABILITY OF INSERVICE TRAINING PROGRAMS IN CLP $(N=26)$

\begin{tabular}{|l|c|c|c|c|}
\hline & \multicolumn{4}{|c|}{ Response (\%) } \\
\hline Survey Item & No & Yes & $\begin{array}{c}\text { Don't } \\
\text { Know }\end{array}$ & $\begin{array}{c}\text { No } \\
\text { Response }\end{array}$ \\
\hline $\begin{array}{l}\text { 2a. Postnatal staff training in cleft lip } \\
\text { 土palate }\end{array}$ & 57.7 & 26.9 & 7.7 & 7.7 \\
\hline $\begin{array}{l}\text { 11. Available CLP inservice } \\
\text { education to staff }\end{array}$ & 69.2 & 15.4 & 7.7 & 7.7 \\
\hline
\end{tabular}

\section{Perceived Need for Inservice Education Programs in CLP}

Research Question 5a asked, "Do hospital personnel perceive a need for inservice education programs?" Question 5a was answered through analyzing responses to item $2 b$ of the survey. Item $2 b$ asked if the respondents believed inservice education on the care of infants with cleft lip and/or palate would be beneficial for their hospital's nursing staff and other professionals. Encouragingly, the majority of respondents (84.6\%) indicated it would be beneficial for nursing staff and/or other professionals to receive an inservice education program on the care of infants with cleft lip \pm palate.

Research Question 5b asked, "Is the perceived need for inservices related to the number of births that occur at the respondent's hospital?" Question 5b was answered by descriptively comparing subjects responses to survey item $2 b$, "Do you feel that an inservice education program would be beneficial for your nursing staff or 
other professional in your hospital on the care of infants with cleft lip and/or palate?" and number of births delivered in that respondent hospital. Table 7 shows how low and high birth rate hospitals perceived the need for inservice education. Hospitals with the few births had those respondents who failed to perceive a need for inservice education regarding cleft lip \pm palate. The two hospitals that did not desire inservice education about the care of infants with cleft lip and/or palate had under 60 births in the previous 12 months and no occurrence of newborns with orofacial clefting. Of interest, is that all respondents from hospitals that had an infant born with cleft lip \pm palate in the past year indicated that an inservice education program would be beneficial to their hospital staff.

TABLE 7

Number of BiRTHS COMPARED to PERCEIVED NEED FOR INSERVICE EDUCATION $(N=26)$

\begin{tabular}{|l|c|c|}
\hline & $\begin{array}{c}\text { Few Births } \\
(<300 / \text { year })\end{array}$ & $\begin{array}{c}\text { Many Births } \\
(>300 / \text { year })\end{array}$ \\
\hline Yes, perceive a need for inservice education & 11 & 13 \\
\hline $\begin{array}{l}\text { No, fail to perceive a need for inservice } \\
\text { education }\end{array}$ & 2 & 0 \\
\hline
\end{tabular}

Descriptive Analysis of Subjects' Responses to Open-Ended Survey Items

Open-ended survey items 12 through 16 inquired about educational interests, referral systems, current inservice education programs, and effects of managed care. 
Over half of the respondents provided descriptive responses to 1 or more of these open-ended survey items.

Educational interests. Survey item 12 asked respondents what particular area in relation to cleft lip and/or palate would they like to see presented in an inservice education program. Table 8 summarizes areas of inservice educational interest expressed by respondents. Eighty-two percent of the respondents answered survey item 12 making it the most answered open-ended question. Half of the respondents indicated an interest in feeding issues. About one third of the respondents indicated interest in receiving information about parent education and counseling and medical management of the newborn born with orofacial clefting.

TABLE 8

SUMMARY OF SUBJECTS' OPEN-ENDED RESPONSES REGARDING EDUCATIONAL INTERESTS $(N=28)$

\begin{tabular}{|l|c|}
\hline $\begin{array}{c}\text { Responses in Order of Frequency from Highest } \\
\text { to Lowest }\end{array}$ & Actual Number of Respondents \\
\hline Feeding/Nutrition & 14 \\
Parent Education/Counseling & 7 \\
Medical Management & 6 \\
Initial Care & 4 \\
Available Referral Sources & 3 \\
Etiology/Causes of Clefting & 2 \\
General Overview & 1 \\
Prognosis Related to Degree of clefting & 1 \\
Cleft Palate Specifically & 1 \\
\hline
\end{tabular}


Referral systems. Survey item 13 asked respondents to describe their current referral system for parents of infants with cleft lip and/or palate. Table 9 lists the different referral systems described by participants. Over a third of the respondents indicated their current referral system consisted of referring the parents of infants with orofacial clefting to another medical center.

\section{TABLE 9}

SUMMARY OF SUBJECTS' OPEN-ENDED RESPONSES

REGARDING REFERRAL SYSTEMS $(N=28)$

\begin{tabular}{|l|c|}
\hline $\begin{array}{c}\text { Responses in Order of Frequency from Highest to } \\
\text { Lowest }\end{array}$ & Actual Number of Respondents \\
\hline Refer to another Medical Center & 7 \\
Physician-to-Physician Referral & 5 \\
Refer to Social Services & 1 \\
Refer to In-house CLP Team & 2 \\
Refer to Support Group & 1 \\
Refer to Specialist & 1 \\
No system set up & 1 \\
\hline
\end{tabular}

Cleft palate team summary. Survey item 14 asked respondents to describe the members of the local Cleft Palate Team(s) that their hospital utilized. Table 10 lists the most frequently cited answers to survey item 14 . Over half of the respondents indicated they had no Cleft Palate Team or did not know the members of the team.

Current CLP inservice education programs. Survey item 15 asked for a description of current inservice education offered to nurses on the topic of cleft lip \pm palate. Table 11 summarizes respondents' descriptions of their hospital's cleft lip 
TABLE 10

SUMMARY OF SUBJECTS' OPEN-ENDED RESPONSES REGARDING

Hospital's Cleft Palate Team $(N=28)$

\begin{tabular}{|l|c|}
\hline \multicolumn{1}{|c|}{$\begin{array}{c}\text { Responses in Order of Frequency from Highest } \\
\text { to Lowest }\end{array}$} & Actual Number of Respondents \\
\hline No Team & 12 \\
Unknown & 4 \\
Developmental Pediatrician, Speech-Language & \\
Pathologist, Occupational Therapist, Plastic & \\
Surgeon, Maxilla-Facial Surgeon, Dentist, & 2 \\
Otologist, Orthodontist, Geneticist & \\
Breast-feeding Specialist and Community & 1 \\
Resources & 1 \\
Nurse to Answer Questions & \\
\hline
\end{tabular}

\pm palate inservice education programs. Half of the respondents reported they did not have any current inservice education programs for nurses on the topic of cleft lip \pm palate. Only two respondents were able to state topics covered when asked to describe current inservice education.

Effects of managed care. Survey item 16 asked how managed health care has affected the management of care for infants born with cleft lip \pm palate. Table 12 lists subjects' responses about managed health care effects. Survey item 16 was the second most frequently answered open-ended question. Ten respondents indicated they saw no effect on the management of care for infants born with cleft lip and/or palate from managed health care. 
TABLE 11

SUMMARY OF SUBJECTS' OPEN-ENDED RESPONSES REGARDING

CURRENT CLP INSERVICE PROGRAMS $(N=28)$

\begin{tabular}{|l|c|}
\hline $\begin{array}{c}\text { Responses in Order of Frequency from Highest } \\
\text { to Lowest }\end{array}$ & Actual Number of Respondents \\
\hline No Inservice Education Programs offered & 14 \\
Limited Inservice Education offered & 3 \\
Unknown & 2 \\
How Clefting Surgery is Performed & 1 \\
Feeding Issues & 1 \\
General Overview of Cleft Lip \pm Palate & 1 \\
Information regarding Parent Groups & 1 \\
\hline
\end{tabular}

TABLE 12

SUMMARY OF SUBJECTS' OPEN-ENDED RESPONSES REgARDING

EFFECTS OF MANAGED HEALTH CARE $(\mathrm{N}=28)$

\begin{tabular}{|l|c|}
\hline $\begin{array}{c}\text { Responses in Order of Frequency from Highest } \\
\text { to Lowest }\end{array}$ & Actual Number of Respondents \\
\hline No effects & 10 \\
Unknown effects & 6 \\
Fewer Hospital Visits & 2 \\
Decrease in Hospital Stay & 1 \\
Decrease in Available Education for Parents & \\
and Staff & 1 \\
Decreased Resources & 1 \\
Less Coordinated Care & 1 \\
No Reimbursement for Family Education & 1 \\
\hline
\end{tabular}




\section{Discussion}

The purpose of this study was to survey Oregon hospitals in order to gauge the current status of initial services currently provided by these hospitals to families with infants born with orofacial clefting. This study was a duplication of Scheuerle et al.'s national study done in 1984 with minor modifications in questions asked. The major difference between the two studies was that the study by Scheuerle et al. focused on the two largest hospitals in each state, while this study focused on both large and small hospitals located in Oregon. Differences were expected in birth rate of hospitals, particularly the number, or lack thereof, of infants born with congenital birth deft of clefting in each of the Oregon hospitals. The number of births delivered at respondent hospitals ranged from 47 to 3,362 . Eight of the 26 responding hospitals indicated they had had at least one occurrence of an infant born with orofacial clefting within the past year, which is consistent with the national figures for incidence of cleft lip \pm palate. The national incidence of cleft lip with or without palate as 1 in every 750 births and isolated cleft palate as 1 in every 2,500 births (Berkowitz, 1994).

This investigator was not only pleased with the response rate, but also the diversity of hospitals that responded. This investigator received responses from a wide variety of Oregon hospitals with differences in hospital size and location, ranging from rural to urban making it a comprehensive study of Oregon hospitals. A $52 \%$ response rate occurred which is higher than the $50 \%$ response rate criterion 
Pannbacker and Middleton (1994) report is adequate for survey studies in order for valid statistical analysis and a representative sample.

It is of interest to note that similar to the Scheuerle et al. (1984) study, 1 copy of the survey was sent to each Director of Nursing and each Director of Inservice Education. In the current study, however, over $20 \%$ of the actual survey respondents were not employed in either of these roles. This could be due, in part, to an expansion of hospital job titles and personnel. Hospitals may not currently have as was previously common a specific person on staff with the job title of Director of Nursing and/or Director of Inservice Education. Surveys at some hospitals may have been routed to the best person on staff who could answer questions regarding management and care of newborns with cleft lip \pm palate, while at other hospitals the survey may have failed to make it into the hands of the appropriate personnel at the hospital who felt able to respond to the survey questions.

A number of important findings were revealed in this study. Findings from the 26 Oregon hospitals suggest that adequate assistance is not provided to all new parents of infants with cleft lip and/or palate. This statement is based on the facts that almost $70 \%$ of the hospitals do not provide trained professionals to counsel parents with newborns with orofacial clefting, reading materials or a list of suggested reading materials are provided in only half of the hospitals, only one third of the respondents indicated their hospital offers training programs for the new 
parents, and adaptive feeding equipment is not available in almost $20 \%$ of the hospitals. It was found that identification of cleft lip and palate specialists to these parents is only made in half of the responding hospitals. The level of overall associated services provided to families of newborns with orofacial clefting was found to be related to the birth rate at the respondent's hospital. The fewer babies delivered at a hospital, the lower the level of associated services. The trend for smaller hospitals to provide fewer services for infants born with cleft lip \pm palate is not surprising as there would be less opportunities for resources and personnel devoted to the care and management of these infants to be utilized because of the low occurrence rate. Minimal services that should be provided during the initial management of an infant born with a cleft lip \pm palate include available adaptive feeding equipment, reading material for parents, list of CLP specialists, and referral to a craniofacial team. Even small hospitals with low incidence of infants born with clefts should be prepared to provide this assistance.

Beyond the original research questions, the principal investigator wondered how services were overall across the Oregon hospitals. This question was raised based on the fact that delivering in a large, urban hospital did not assure families access to a high level of associated services. To study this beyond the original research questions, an overall mean rating was computed for associated level of services provided to families of newborns with clefting across responding hospitals. Out of possible range of scores from 0 to 7 , with 0 indicating no associated services 
provided and 7 indicating high level of associated services, the mean was 2.7 . This low level of associated services provided to families of newborns with orofacial clefting in Oregon should be further investigated and addressed.

The study showed that while most hospitals do not provide inservice education programs specifically about clefting for their nursing staff, hospital personnel express desire for such inservice education programs. The survey questionnaire did not elicit information about other general education programs provided. The perceived need for inservice education regarding cleft lip and palate was found to be related to the number of births at the subject's hospital. The fewer births delivered at a hospital, the lower the perceived need for inservice education regarding clefting. This could be related to the need to prioritize health care demands.

Many of the responding hospitals indicated they did not have much experience in caring for infants with cleft lip \pm palate. However, orofacial clefting is usually diagnosed at time of delivery; therefore, hospital nursing personnel need to be prepared to care for the special needs of an infant born with cleft lip \pm palate from birth. The health and welfare of infants born with orofacial clefting relies upon the clinical expertise of the hospital staff serving them (ACPA, 1993). Prompt delivery of appropriate services requires training and education of hospital staff about cleft lip \pm palate so that personnel are ready when an infant with orofacial clefting is born. Most of the responding hospitals do not have specific guidelines set 
up for dealing with parents of infants born with cleft lip and/or palate. Care of the infant is directly related to what information and referrals parents have at the time of birth and when they leave the hospital. The status of nurses' education in the care of parents whose newborn demonstrates an orofacial cleft was found to be deficient in that less than one third train their postnatal staff in management of cleft lip \pm palate, and even fewer offered inservice education programs regarding clefting. Education programs need to be developed and provided for hospital nursing staffs in order to improve the level of associated services for parents and infants with cleft lip \pm palate. Encouragingly many hospitals $(84.6 \%)$ reported an interest in more training and education regarding cleft lip \pm palate. In addition, respondents indicated a wide variety of topics of interest in the area of cleft lip \pm palate. The responsibility of providing more training and education about cleft lip and palate needs to be decided before inservice education programs can be implemented. Survey respondents did not indicate who would provide training regarding the care and management of infants born with clefting. Candidates to provide inservice education could be each hospital's inservice education department, experienced regional craniofacial teams, or a collaboration between the two.

At the beginning of the survey, respondents were asked if they wished to receive an abstract of the survey. More than half of the respondents requested a copy. This indicates interest in initial services in the area of cleft lip and palate. 
Findings obtained from the responses to the open-ended questions which inquired about educational interests, referral systems, current inservice education programs, and effects of managed care provided information about areas of interest and concern for the responding hospital personnel. Many respondents expressed interest in further education about issues related to cleft lip and palate; feeding was the most cited educational interest topic cited. It was found that most responding hospitals did not have an established system regarding referrals for parents of infants with cleft lip and/or palate. Few respondents were able to list the type of medical professionals that make up a cleft palate/craniofacial team. Again, almost no respondents were able to cite specific inservice education program topics offered to nurses on the topic of cleft lip and palate. The respondents varied greatly on their impressions, from no effects to great impacts, of how managed health care has affected management of care for infants born with cleft lip \pm palate.

To conclude, this study was a duplication of a national study done in 1984 by Scheuerle et al. with minor modifications in questions asked. Despite the one major difference between the two studies in that Scheuerle et al.'s study focused on the two largest hospitals in each state, while this study focused on both large and small hospitals located in Oregon, similar results were found. The two studies had the same response rate and more respondents were from Nursing than from Inservice Education. Both studies concluded that adequate assistance and training for parents of newborns with cleft lip \pm palate are not provided by hospitals due to low level of 
associated services provided. Scheuerle et al. cited a major implication of their study was the need to create programs and provide inservice nursing education on care and management of families when an infants is born with cleft lip \pm palate. The responsibility of providing this inservice nursing education has yet to be defined in Oregon, which may explain why this study, completed 13 years after the Scheuerle et al. study, found similar results. 


\section{CHAPTER V}

\section{SUMMARY AND IMPLICATIONS}

\section{Summary}

The purpose of this thesis was to investigate the current status of initial nursing services provided by hospitals in the State of Oregon to families with newborns with cleft lip and/or palate. This study was accomplished by duplicating a national survey of nursing care for parents and infants with cleft lip and palate originally done by Scheuerle et al. in 1984 . The current study, using the original questionnaire format with 12 forced choice (yes/no) items and 5 open-ended descriptive information items, focused on services in Oregon. Questionnaires were mailed to the directors of nursing and directors of inservice education at 50 Oregon hospitals registered by the American Hospital Association. Twenty-eight subjects representing 26 hospitals responded. Response rate to participate in the study was $52 \%$. Interrater institutional reliability on the survey questionnaire was found to be at $80 \%$. Given the limitations of the study, the following is a summary of the results which support all of the study's original hypotheses unless otherwise indicated:

1. Hospital nurses do not provide adequate assistance to new parents of infants with cleft lip and palate as evidenced by: almost $70 \%$ of hospitals do not 
provide trained professionals to counsel parents with newborns with orofacial clefting; reading materials or suggested reading materials are provided in only half of the hospitals; only one third of the respondents indicated their hospital offers training programs for the new parents; and adaptive feeding equipment is not available in almost $20 \%$ of the responding hospitals. The study's original hypothesis that " $25 \%$ or more of hospitals will report that they fail to provide adequate assistance to parents of newborns with clefts" was supported in terms of counseling, training, and provision of applicable reading materials. This original study hypothesis was rejected, however, in terms of assistance regarding adaptive feeding techniques, as only $19 \%$ of hospitals report that they fail to provide adaptive feeding equipment.

2. Hospital nurses do not consistently identify specialists to these parents as evidenced by the fact that only half of the responding hospitals identify craniofacial disorders specialists to parents.

3. The level of associated services provided to families of infants with orofacial clefting was found to be related to the number of births that occur at the subjects' place of employment. Almost all respondents from hospitals with less than 300 births per year provided a low level of associated services to parents with newborns with cleft lip \pm palate. While respondents from hospitals with more than 300 births per year provided an almost equal number of low and high level of associated services. 
4. Most hospitals do not provide nurses with an inservice education program in cleft lip and palate as indicated by the low percentage of responding hospitals that provide postnatal staff training in cleft lip \pm palate $(26.9 \%)$ and even lower percentage of hospitals that provide inservice education regarding cleft lip \pm palate to their staff $(15.4 \%)$.

5. There is a perceived need for inservice education programs and this need appears to be related to the number of births that occur in the hospital in which the respondent worked. Most respondents indicated a desire for inservice education regarding clefting. However, the hospitals with the fewest births did not perceive the need for inservice education regarding cleft lip \pm palate. The latter finding was unexpected and not in support of the study's original hypotheses.

\section{Implications}

\section{Clinical Implications}

Results from a study completed by MacDonald (1979) indicate that parents' needs were most apparent during critical times, including during birth. During these critical periods they look to professionals for information, reassurance, and effective coordination between specialists. Martin (1995) found that prompt referrals, integrated and individualized advice on feeding techniques, and health professionals who took the time to listen were found to give parents greater confidence and reduce their anxiety. 
The results of this study present evidence for a need in providing inservice education programs for nursing staffs in hospitals in the State of Oregon. There was an extremely low number of hospitals that were found to provide training in the management of cleft lip \pm palate to their staff. Inservice education regarding issues related to cleft lip \pm palate was found to offered in very few hospitals. Educating the nursing staff about issues surrounding the initial care of newborns with cleft lip \pm palate and providing them with available resources to gain more information for themselves and the families they care for would have a direct impact on families with newborns with orofacial clefting. Inservices could be approached in a variety of ways tailored to specific hospital preference and/or needs. Information regarding clefting could be included in a broader based inservice program about craniofacial syndromes or feeding disorders. Encouragingly most of the responding hospitals expressed a desire for inservice education regarding cleft lip \pm palate. Another way to address this need for more education about the care and management of cleft lip \pm palate is to include it in the curriculum at nursing schools.

The responsibility of providing needed inservice education to hospital nurses and professionals throughout Oregon hospitals should be initiated. This could be done by respective hospital inservice education department or perhaps experienced cleft palate/craniofacial teams should be contacted to provide this inservice education. There are many options of means of communication (e.g., video conferencing, videotapes, internet, etc.) available for carrying out inservice 
education programs. There are currently four agencies that house cleft palate/craniofacial teams within the State of Oregon. These cleft palate/craniofacial teams are housed in the following facilities: Oregon Health Sciences University Child Development and Rehabilitation Center in both Portland and Eugene, Legacy Emanuel Hospital and Health Center in Portland, and Kaiser Permanente's Sunnyside Medical Center in Clackamas. These agencies are the best source of current information regarding care and treatment of infants with orofacial clefting and therefore the best candidates for providing inservice education programs. Another source for inservice information is the American Cleft Palate-Craniofacial Association, a national organization whose purposes include "to encourage the improvement of clinical services to persons with cleft palate and other associated deformities."

One fact that was made apparent by this research study is that very few hospitals had a set protocol prepared in the events of the birth of an infant with cleft lip \pm palate. Diagnosis of cleft lip \pm palate is usually made at the time of birth. To ensure there is no delay in services provided and/or referrals made to cleft lip and palate specialists it is imperative that guidelines be set up at every hospital regarding the care and management of newborns with cleft lip \pm palate.

Another implication of this study that was briefly addressed is the effects of managed health care on services provided to newborns with cleft lip \pm palate. Respondents reported a broad range of effects from managed health care ranging 
from no impact to decreased services provided for families with infants born with orofacial clefting. It would behoove professionals specializing in cleft lip and palate to educate managed health care organizations on the specialized care needed by individuals with cleft lip \pm palate. The possible short- and long-term ramifications of reduction or cessation of comprehensive care should be conveyed.

\section{Future Research Implications}

Questionnaires of the nature of this study often generate additional questions to be explored. Direct study of hospital care of families of newborns with clefts may provide more detailed and perhaps, accurate, insight into the strengths and weaknesses of this component of health care. Programs could be developed and carried out based on these findings. Replication of the study after inservice education is provided to see if associated level of care has been improved for families with newborns with orofacial clefting should be explored. Data regarding who provided the inservice education and topics addressed would be important in order to gain a clear and accurate picture of the effects of inservice education to nursing staff and other professionals. In addition, research studies should look into how often inservice education is needed in order to maintain a high level of care and management for infants born with cleft lip \pm palate.

Another area of interest would be to survey parents with infants born with cleft lip \pm palate to determine how they would rate initial services they received at the time of their infant's birth. This could result in greater insight into what areas of 
care and treatment are important from a parent's perspective. The insight gained from this will help determine a hospital's policy and protocol for care and management of parents of newborns with cleft lip \pm palate.

To analyze interrater reliability more completely, a higher response rate from two respondents per hospital, Director of Nursing and the Director of Inservice Education or other appropriate personnel must be obtained. This would enable a better assessment of whether responses were consistent and accurate within each hospital. It is hoped that with this increased knowledge, initial care for infants with cleft lip and/or palate can be improved. 


\section{REFERENCES}

Abdoney, M., Habal, M. B., Scheuerle, J., \& Rans, N. P. (1988). Cleft palate teams and the craniofacial centers in Florida: A state network. Florida Dental Journal, 25-27, 53.

American Cleft Palate-Craniofacial Association. (1993). Parameters for the evaluation and treatment of patients with cleft lip/palate or other craniofacial anomalies. Cleft Palate-Craniofacial Journal, 30 (Suppl 1).

American Hospital Association. (1995). American Hospital Association guide to the health care field. Chicago: Author.

Andrews, K. N., Anderson, L. E., \& Glanze, W. D. (Eds.). (1994). Mosby's medical, nursing, and allied health dictionary (4th ed.). St. Louis: Mosby.

Aspinall, C. L. (1995). Family focused ethics. Cleft Palate-Craniofacial Journal, 32, 507-509.

Berkowitz, S. (1994). The cleft palate story. Carol Stream, IL: Quintessence Publishing Company.

Brine, E. A., Rickard, K. A., Brady, M. S., Liechty, E. A., Manatunga, A., Sadove, M., \& Bull, M. J. (1994). Effectiveness of two feeding methods in improving energy intake and growth of infants with cleft palate: A randomized study. Journal of the American Dietetic Association, 94, 732-738.

Bronshtein, M., Mashiah, N., Blumenfeld, I., \& Blumenfeld, Z. (1991). Pseudoprognathism: An auxiliary ultrasonographic sign for transvaginal ultrasonographic diagnosis of cleft lip and palate in the early second trimester.

Clifford, E., \& Crocker, E. C. (1971). Maternal responses: The birth of a normal child as compared to the birth of a child with a cleft. Cleft Palate Journal, 8 , 298-306.

Dommergues, M., Lemerrer, M. Couly, G., Delezoide, A. L., \& Dumex, Y. (1995). Prenatal diagnosis of cleft lip at 11 menstrual weeks using embryoscopy in the Van Der Woude syndrome. Prenatal Diagnosis, 15, 378-381. 
Drotar, D., Baskiewicz, A., Irvin, N. Kennell, J., \& Klaus, M. (1975). The adaptation of parents to the birth of an infant with a congenital malformation: A hypothetical model. Pediatrics, 56, 710-717.

Famighetti, R. (Ed.). (1995). The world almanac and book of facts 1996 Mahwah, NJ: Funk \& Wagnallis Corporation.

Gorlin, R. J. (1993). Development and genetic aspects of cleft lip and palate. In K. T. Moller \& C. D. Starr (Eds.), Cleft palate: Interdisciplinary issues and treatment (pp. 25-48). Austin, TX: Pro-Ed, Inc.

Jones, M. C. (1988). Etiology of facial clefts: Prospective evaluation of 428 patients. Cleft Palate Journal, 25, 16-20.

MacDonald, S. K., (1979). Parental needs and professional responses: A parental perspective. Cleft Palate Journal, 16, 188-192.

Martin, V. (1995). Helping parents cope. Nursing Times, 91, 38-40.

McWilliams, B. S., Morris, H., \& Shelton, R. L. (1990). Cleft palate speech. (2nd ed.). Philadelphia: B. C. Decker, Inc.

Moller, K. T., \& Starr, C. D. (Eds.). (1993). Cleft palate: Interdisciplinary issues and treatment. Austin, TX: Pro-Ed, Inc.

Pannbacker, M. \& Middleton, G. F. (1994). Introduction to clinical research in communication disorders. San Diego, CA: Singular Publishing Group, Inc.

Pannbacker, M. \& Scheuerle, J. (1993). Parents' attitude toward family involvement in cleft palate treatment. The Cleft Palate Journal, 30, 87-89.

Scheuerle, J., Olsen, S., Guilford, A. M., Redding, B., \& Habal, M. B. (1984). A survey of nursing care for parents and infants with cleft lip and palate. The Cleft Palate Journal, 21, 110-114.

Shprintzen, R. J., Siegel-Sadewitz, V. L., Amato, J., \& Goldberg, R. B. (1985). Anomalies associated with cleft lip, cleft palate, or both. American Journal of Medical Genetics, 20, 585-595.

Spriestersbach, D. C. (1961). Counseling parents of children with cleft lip and palate. Journal of Chronic Diseases, 13, 244-252. 
Strauss, R. P., Sharp, M. C., Lorch, S. C., \& Kachalia, B. (1995).

Physicians and the communication of "bad news": Parent experiences of being informed of their child's cleft lip and/or palate. Pediatrics, 96, 82-89.

Wicka, D. K., \& Falk, M.L. (1982). Advice to parents of a cleft palate child. (2nd ed.). Springfield, IL: Charles C. Thomas Books. 
APPENDIX A

LIST OF ACCREDITED OREGON HOSPITALS 


\section{ACCREDITED OREGON HOSPITALS}

\begin{tabular}{|l|l|}
\hline CITY & HOSPITAL \\
\hline Albany & Albany General Hospital \\
\hline Ashland & Ashland Community Hospital \\
\hline Astoria & Columbia Memorial Hospital \\
\hline Baker City & St. Elizabeth Health Services \\
\hline Bend & St. Charles Medical Center \\
\hline Burns & Harney District Hospital \\
\hline Clackamas & Kaiser Foundation Hospital \\
\hline Coos Bay & Bay Area Hospital \\
\hline Coquille & Coquille Valley Hospital \\
\hline Corvallis & Good Samaritan Hospital Corvallis \\
\hline Cottage Grove & Cottage Grove Hospital \\
\hline Dallas & Valley Community Hospital \\
\hline Enterprise & Wallowa Memorial Hospital \\
\hline Eugene & Sacred Heart Medical Center \\
\hline Florence & Peace Harbor Hospital \\
\hline Forest Grove & Tuality Forest Grove Hospital \\
\hline Grants Pass & Three Rivers Community Hospital and Health Center \\
\hline Hermiston & Good Shepherd Community Hospital \\
\hline Hillsboro & Tuality Community Hospital \\
\hline Hood River & Hood River Memorial Hospital \\
\hline John Day & Blue Mountain Hospital \\
\hline Klamath Falls & Merle West Medical Center \\
\hline LaGrande & Grande Ronde Hospital \\
\hline Lakeview & Lake District Hospital \\
\hline & \\
\hline
\end{tabular}




\begin{tabular}{|l|l|}
\hline CITY & HOSPITAL \\
\hline Lebanon & Lebanon Community Hospital \\
\hline Lincoln City & North Lincoln Hospital \\
\hline Madras & Mountain View Hospital District \\
\hline McMinnville & McMinnville Community Hospital \\
\hline Medford & Rouge Valley Medical Center \\
\hline Milwaukie & Providence Milwaukie Hospital \\
\hline Newberg & Providence Newberg Hospital \\
\hline Newport & Pacific Communities Hospital \\
\hline Ontario & Holy Rosary Medical Center \\
\hline Oregon City & Willamette Falls Hospital \\
\hline Pendleton & St. Anthony Hospital \\
\hline Portland & $\begin{array}{l}\text { Legacy Emanuel Hospital and Health Center } \\
\text { Legacy Good Samaritan Hospital } \\
\text { Portland Adventist Medical Center } \\
\text { Providence Portland Medical Center } \\
\text { Providence St. Vincent Medical Center } \\
\text { University Hospital }\end{array}$ \\
\hline Central Oregon District Hospital \\
\hline Reaside & Lower Umpqua Hospital District \\
\hline Silverton & Mercy Medical Center \\
\hline Springfield & Salem Hospital \\
\hline Stayton & Providence Seaside Hospital \\
\hline Tillamook & Silverton Hospital \\
\hline Salem & McKenzie-Willamette Hospital \\
\hline Santiam Memorial Hospital \\
\hline Tillamook County General Hospital \\
\hline
\end{tabular}


APPENDIX B

COVER LETTER FOR SUBJECTS 


\author{
Department of Speech Communication \\ Speech \& Hearing Sciences Program \\ Portland State University \\ Post Office Box 751 \\ Portland, Oregon 97207-0751
}

April 11, 1997

Dear Director of Nursing and/or Directors of Inservice Education:

As a graduate student in speech-language pathology, with a special interest in individuals with cleft lip \pm palate, I am conducting a study of the initial care provided to newborns with clefting in hospitals in the state of Oregon. It is my hope that the study will enlighten us to areas of strengths and weaknesses in the care of these infants. If improvement is needed, then subsequent education can be focused in the proper areas.

You are invited to participate in this study. You are assured of complete confidentiality. Participation would involve approximately 15 minutes of your time to complete the enclosed consent form and questionnaire. Please note: if you serve as both Director of Nursing and as Director of Inservice Education, it is possible that you will receive two copies of this questionnaire. Please only complete it once and simply return the unused copy.

I am willing to mail a copy of the survey results to those who participate. If you wish to receive this information, be sure to indicate your interest on the last page of the enclosed questionnaire.

I would be happy to answer any questions you might have, call me at (503) 2214956. Thank you for your assistance in helping me complete my graduate research project.

Sincerely,

Kirsten J. Lindaas 
APPENDIX C

CONSENT FORM FOR SUBJECTS 
I, project on April , 1997. , agree to take part in this research

I understand that the study involves filling out a questionnaire and mailing it back in a pre-addressed stamped envelope.

I understand that, because of this study, I may risk the inconvenience of time.

Kirsten J. Lindaas has told me that the purpose of the study is to investigate the current status of initial services provided by hospitals in the state of Oregon to families with newborns with cleft lip and/or palate, in order to gauge if these services need improvement.

I may not receive any direct benefit from taking part in this study. But the study may help to increase knowledge that may help others in the future.

Kirsten J. Lindaas has offered to answer any questions I have about the study and what I am expected to do.

She has promised that all information I give will be kept confidential to the extent permitted by law, and that the names of all people in the study will be kept confidential.

I understand that I do not have to take part in this study, and that this will not affect my relationship with Portland State University.

I have read and understand the above information and agree to take part in this study.

SIGNATURE

DATE

If you have concerns or questions about this study, please contact the Chair of the Human Subjects Research Review Committee, Research and Sponsored Projects, 105 Neuberger Hall, Portland State University, (503) 725-3417. 
APPENDIX D

STUDY SURVEY QUESTIONNAIRE 


\section{Questionnaire \\ Initial Nursing Care for Infants with Cleft Lip and/or Palate}

Job Title of Respondent:

Name of Hospital:

Circle the answer that best reflects your response to the following questions. Your answers will remain anonymous. Please fill in the blanks where indicated.

1a. Has there been an occurrence of cleft lip and/or palate births in your hospital during the past year?

YES NO I DON'T KNOW

1b. If yes, how many if known?

2a. Are your postnatal staff given training in the management of the cleft lip and/or palate infant?

YES NO I DON'T KNOW

2b. Do you feel that an inservice education program would be beneficial for your nursing staff or other professionals in your hospital on the care of infants with cleft lip and/or palate?

YES NO I DON'T KNOW

3. Does your hospital have adaptive feeding equipment readily available for the newborn with cleft lip and/or palate?

YES NO I DON'T KNOW

4. Does your hospital provide training or education programs for new parents of a newborn with cleft lip and/or palate?

YES NO I DON'T KNOW

5. Does your hospital provide reading materials and/or a list of suggested reading materials for new parents of an infant with cleft lip and/or palate?

YES NO I DON'T KNOW

6. Are there trained professionals on staff at your hospital who work specifically with individuals with craniofacial anomalies?

YES

No

I DON'T KNOW 
7. Does your hospital provide parents with a list of professionals who specifically work with the care and management of infants with cleft lip and/or palate?

YES NO I DON'T KNOW

8. Are there trained professionals on staff at your hospital who counsel parents of an infant with cleft lip and/or cleft palate?

YES NO I DON'T KNOW

9. Are referrals to Cleft Lip/Palate teams given to parents?

YES NO I DON'T KNOW

10a. Is there a Cleft Lip/Palate parent group for parent's of children with cleft lip and/or palate in your area?

YES NO I DON'T KNOW

10b. If yes, are referrals to these Cleft Lip/Palate parent groups given to the parents?

YES NO I DON'T KNOW

11. Are there inservice education programs on the care of infants with cleft lip and/or palate available for nurses?

YES NO I DON'T KNOW

12. If such a workshop were to be presented to your staff what particular area in relation to cleft lip and/or palate would you like to see presented? Please describe below. 
13. Describe your current referral system for parents and infants of cleft lip/palate to other professionals/specialists.

14. Describe the members of the local Cleft Palate Team(s) that your hospital utilizes.

15. Describe current inservice education for nurses on the topic of cleft lip/palate.

16. Describe how managed health care has affected the management of care for infants born with cleft lip and/or palate.

PLEASE RETURN COMPLETED QUESTIONNAIRE in the enclosed preaddressed stamped envelope by to L. Letcher-Glembo, Department of Communication, Speech \& Hearing Sciences Program, Portland State University, Post Office Box 751, Portland, Oregon, 97207-0751. Thanks for your cooperation!

$\square$ Check here if you would like to receive an abstract of survey results. 


\section{APPENDIX E}

\section{SUBJECT RECRUITMENT FOLLOW-UP POSTCARD}


Dear Director of Nursing and/or Inservice Education:

Recently a questionnaire was mailed to you which was designed to assess initial services provided by hospitals to families with newborns with cleft lip and/or palate.

If you have already completed and returned the questionnaire, please accept my sincere thanks. If not, please take a few minutes from your busy schedule in order to respond. If you need another copy, don't hesitate to call me at (503) 221-4956. Please return the completed questionnaire by May 19, 1997. Your cooperation and assistance will be greatly appreciated.

Thank you.

Kirsten J. Lindaas

Speech \& Hearing Sciences Program

Portland State University 


\section{APPENDIX F}

\section{DATA CODING}


Variable 1a: Incidence of cleft lip/palate

This variable measured if there were any infants born with cleft lip and/or palate in the hospital in the past year.

Quantitative analysis

Coding: Yes

No $\quad=0$

I Don't Know = N/C (Not Coded)

Variable $1 b$ : Number of cleft lip/palate births

This variable measured the number of infants born with cleft lip and/or palate in the hospital in the past year.

Quantitative analysis, no coding needed.

Variable 2a: Training of postnatal staff

This variable measured if postnatal staff are given training in the care and management of infants with cleft lip and/or palate.

Quantitative analysis.

Coding: Yes $\quad=1$

No $\quad=0$

I Don't Know $\quad=\mathrm{N} / \mathrm{C}$

Variable $2 b$ : Desire for inservice education programs

This variable measures if hospitals desire any inservice education programs for nursing staff on the care of infants with cleft lip and/or palate.

Quantitative analysis

Coding: Yes

No $\quad=0$

I Don't Know $\quad=$ N/C

Variable 3: Availability of adaptive feeding equipment

This variable measured if adaptive feeding equipment is available for the family to use to feed their newborn with cleft lip and/or palate.

Quantitative analysis.

Coding: Yes

No $\quad=0$

I Don't Know $\quad=$ N/C 
Variable 4: Training/education offered to new parents of infants with cleft lip and/or palate

This variable measured if the hospital provides training or education programs for new parents of infants with cleft lip and/or palate.

Quantitative analysis.

Coding:

$$
\begin{array}{ll}
\text { Yes } & =1 \\
\text { No } & =0 \\
\text { I Don't Know } & =\text { N/C }
\end{array}
$$

Variable 5: Educational reading materials offered

This variable measured if hospitals provide educational reading materials and/or a list of suggested reading materials for new parents of an infant with cleft lip and/or palate.

Quantitative analysis

Coding:

$\begin{array}{ll}\text { Yes } & =1 \\ \text { No } & =0 \\ \text { I Don't Know } & =\text { N/C }\end{array}$

Variable 6: Professionals trained specifically with craniofacial anomalies at hospital This variable measured if hospitals have professionals trained to work specifically with craniofacial anomalies on site.

Quantitative analysis

Coding:

$\begin{array}{ll}\text { Yes } & =1 \\ \text { No } & =0 \\ \text { I Don't Know } & =\mathrm{N} / \mathrm{C}\end{array}$

Variable 7: List of professionals trained specifically with craniofacial anomalies given

This variable measured if hospitals provide parents with a list of professionals who specifically work with the care and management of infants with cleft lip and/or palate.

Quantitative analysis

$\begin{array}{lll}\text { Coding: } & \text { Yes } & =1 \\ & \text { No } & =0 \\ & \text { I Don't Know } & =\text { N/C }\end{array}$


Variable 8: Trained professionals available to provide counseling This variable measured if the hospitals provide trained professionals to counsel parents of infants with cleft lip and/or palate.

Quantitative analysis

Coding: Yes $=1$

No $\quad=0$

I Don't Know = N/C

Variable 9: Referrals to cleft palate-craniofacial teams

This variable measured if hospitals refer parents to cleft palate-craniofacial teams.

Quantitative analysis

Coding: Yes $\quad=1$

No $\quad=0$

I Don't Know $\quad=\mathrm{N} / \mathrm{C}$

Variable 10a: Available cleft lip and/or palate parent support groups in the area This variable measured if there are cleft lip and/or palate parent support groups in the area.

Quantitative analysis

Coding: Yes $\quad=1$

No $\quad=0$

I Don't Know $\quad=$ N/C

Variable 10b: Referrals to cleft lip and/or palate parent support groups

This variable measured if hospitals refer parents of infants with cleft lip and/or palate to parent support groups.

Quantitative analysis

Coding: Yes $\quad=1$

No $\quad=0$

I Don't Know $\quad=\mathrm{N} / \mathrm{C}$

Variable 11. Available cleft lip and/or palate inservice education programs for nurses

This variable measured if hospitals provide inservice education programs for nursing staff regarding cleft lip and/or palate.

Quantitative analysis

Coding: Yes $=1$

No $\quad=0$

I Don't Know $\quad=\mathrm{N} / \mathrm{C}$ 
Variable 12: Description of educational interests in the areas of cleft lip and/or palate

This variable enabled description of educational interests desired in the areas of cleft lip and/or palate.

Qualitative analysis, no coding needed.

Variable 13: Description of current referral system. This variable enabled description of the hospitals' current referral systems for referring parents and infants of cleft lip and/or palate to other professionals and specialists in the area.

Qualitative analysis, no coding needed.

Variable 14: Description of cleft palate-craniofacial team utilized This variable enabled description of what members are part of the local cleft palatecraniofacial team the hospitals utilize.

Qualitative analysis, no coding needed.

Variable 15: Description of current inservice education programs

This variable enabled description of availability of current inservice education programs for nurses on the topic of cleft lip and/or palate.

Qualitative analysis, no coding needed.

Variable 16: Description of the effects of managed health care

This variable enabled description of how managed health care has affected the management of care for infants born with cleft lip and/or palate.

Qualitative analysis, no coding needed. 